\title{
Environmental risk factors and Parkinson's disease: an umbrella review of meta-analyses
}

\begin{tabular}{|r|l|}
\hline Journal: & Movement Disorders \\
\hline Manuscript ID: & Draft \\
\hline Date Submitted by the Author: & n/a \\
\hline Complete List of Authors: & $\begin{array}{l}\text { Bellou, Vanesa; University of Ioannina Medical School, Department of } \\
\text { Hygiene and Epidemiology } \\
\text { Belbasis, Lazaros; University of Ioannina Medical School, Department of } \\
\text { Hygiene and Epidemiology } \\
\text { Tzoulaki, Ioanna; Imperial College London, Department of Biostatistics and } \\
\text { Epidemiology } \\
\text { Evangelou, Evangelos; University of Ioannina Medical School, Department } \\
\text { of Hygiene and Epidemiology } \\
\text { Ioannidis, John; Stanford University School of Medicine, Department of } \\
\text { Medicine }\end{array}$ \\
\hline Keywords: & $\begin{array}{l}\text { Parkinson's disease, risk factors, umbrella review, epidemiology, } \\
\text { environment }\end{array}$ \\
\hline
\end{tabular}




\section{Environmental risk factors and Parkinson's disease: an umbrella review of meta-analyses}

Vanesa Bellou $^{1}$, Lazaros Belbasis ${ }^{1}$, Ioanna Tzoulaki ${ }^{1,2,3}$, Evangelos Evangelou ${ }^{1,2}$, John P A Ioannidis ${ }^{4,5,6,7}$

${ }^{1}$ Department of Hygiene and Epidemiology, University of Ioannina Medical School, Ioannina, Greece

${ }^{2}$ Department of Biostatistics and Epidemiology, Imperial College London, London, UK

${ }^{3}$ MRC-PHE Centre for Environment and Health, Imperial College London, London, UK

${ }^{4}$ Department of Medicine, Stanford Prevention Research Center, Stanford, CA, USA

${ }^{5}$ Department of Health Research and Policy, Stanford University School of Medicine, Stanford, CA, USA

${ }^{6}$ Meta-Research Innovation Center at Stanford (METRICS), Stanford University, Stanford, CA, USA

${ }^{7}$ Department of Statistics, Stanford University School of Humanities and Sciences, Stanford, CA, USA

Corresponding Author: John P.A. Ioannidis, MD, DSc, Medical School Office Building, Room X306, 1265 Welch Rd, Stanford, CA 94305, USA. Tel: $+650-7255465$, Fax: $+650-7256247$ 
Count of characters in title: 87

Number of words in abstract: 250

Number of words in main text: 3,700

Running head: Environmental risk factors and Parkinson's disease

Number of figures: 1

Number of tables: 3

Keywords: Parkinson's disease, risk factors, environment, epidemiology

Acknowledgement statement: There was no funding source for this study. All authors had full access to all the study data. The corresponding author had final responsibility for the decision to submit for publication.

\section{Author contributions}

VB and LB had the original idea for the manuscript and all authors contributed to design the study. VB, LB performed the analyses and all authors interpreted the results. VB, LB and JPAI wrote the first draft of the manuscript. All authors critically reviewed, wrote and approved the final version.

\section{Conflict of interest}

The authors declare that there are no conflicts of interest. 


\section{Abstract}

Background: Environmental exposures underlie to a great extent the causation of Parkinson's disease. We aimed to summarise the environmental risk factors that have been studied for potential association with Parkinson's disease, assess the presence of diverse biases, and identify the risk factors with the strongest support.

Methods: We searched PubMed from inception to April 16, 2015, to identify systematic reviews and meta-analyses of observational studies that examined associations between environmental factors and Parkinson's disease. For each metaanalysis we estimated the summary effect size by use of random-effects and fixedeffects models, the $95 \%$ confidence interval and the $95 \%$ prediction interval. We estimated the between-study heterogeneity expressed by $\mathrm{I}^{2}$, evidence of small-study effects and evidence of excess significance bias.

Results: Overall, 66 unique meta-analyses including primary studies of different risk factors and Parkinson's disease were examined, covering diverse biomarkers, dietary factors, drugs, medical history or comorbid diseases, exposure to toxic environmental agents and habits. 34 of 66 meta-analyses had results that were significant at p-values $<0.05$ and 20 at $p$-values $<0.001$ by random effects. Evidence for an association was highly suggestive (more than 1000 cases, $\mathrm{p}<10^{-6}$ by random effects, and largest study with 95\% CI excluding the null) for anxiety or depression, beta-blockers, head injury, physical activity, serum uric acid, and smoking. However, all of them had high heterogeneity and/or some hints for bias.

Conclusion: Many environmental factors have substantial evidence of association with Parkinson's disease, but several, perhaps most, of them may reflect reverse causation, residual confounding, information bias, sponsor conflicts or other caveats. 


\section{Introduction}

Parkinson's disease (PD) is the second most common neurodegenerative disorder, after Alzheimer's disease. ${ }^{1}$ The prevalence of PD is rising steadily with age; reaching 1,903 per 100,000 in older than age $80^{2}$ and is expected to impose an increasing social and economic burden on societies as population ages. ${ }^{1}$ Approximately 630,000 people in the United States had been diagnosed with PD in 2010, with diagnosed prevalence likely to double by $2040 .^{3}$ In USA, the economic burden of PD exceeds $\$ 14.4$ billion in 2010 (approximately $\$ 22,800$ per patient) and it is projected to grow substantially over the next few decades. ${ }^{3}$

Major gene mutations cause only a small proportion of all cases and about $90 \%$ of cases are sporadic. ${ }^{4}$ To our knowledge, there is no previous attempt to summarize the evidence from existing meta-analyses on non-genetic risk factors for Parkinson's disease. We performed an umbrella review of the evidence across existing systematic reviews and meta-analyses of observational studies. Our aim is to provide an overview of the range and validity of the reported associations of diverse environmental risk factors with PD by evaluating whether there is evidence for biases in this literature. Finally we pinpoint which of the previously studied associations that have been synthesized with meta-analyses have the strongest evidence for association.

\section{Methods}

Search strategy and eligibility criteria

We conducted an umbrella review, a systematic collection and evaluation of multiple systematic reviews and meta-analyses performed on a specific research topic. ${ }^{5}$ The 
methods of the umbrella review are standardized and follow exactly the same principles as a previous umbrella review on risk factors for multiple sclerosis. ${ }^{6} \mathrm{We}$ systematically searched PubMed from inception to April 16, 2015 to identify systematic reviews and meta-analyses of observational studies examining associations of environmental (non-genetic) factors and biomarkers with PD. The search strategy used the keywords Parkinson* AND ("systematic review" OR meta-analysis). The full text of potentially eligible articles was scrutinized independently by two investigators (VB, LB). We excluded meta-analyses that investigated the association between genetic markers and risk for PD as these factors have been examined elsewhere. ${ }^{7}$ When a study included meta-analyses of both genetic and environmental risk factors, we only extracted information on the latter. Moreover, meta-analyses with an outcome related to progression of PD or severity of symptoms were excluded. We also excluded meta-analyses examining PD as a risk factor for other medical conditions. We did not apply any language restrictions. When more than one metaanalyses on the same research question was eligible, the meta-analysis with the largest number of component studies with data on individual studies' effect sizes was retained for the main analyses. We kept a record of other meta-analyses focused on the same risk factor.

\section{Data extraction}

Data extraction was performed independently by two investigators (VB, LB), and in case of discrepancies the final decision was that of a third investigator (EE). From each eligible article, we recorded the first author, journal, year of publication, the examined risk factors and the number of studies considered. If a quantitative synthesis was done, we also extracted the study-specific relative risk estimates (mean difference, risk ratio, odds ratio, hazard ratio or incident risk ratio) along with the 
corresponding $\mathrm{CI}$ and the number of cases and controls in each study for each risk factor. Furthermore, we recorded the study design of individual studies. We recorded whether the published meta-analyses applied any criteria to evaluate the quality of the included observational studies; when such an appraisal was performed, we extracted the information on this qualitative assessment. Whenever the studies used several control groups, we extracted the data considering the healthy controls as control group.

\section{Statistical analysis}

For each meta-analysis, we estimated the summary effect size and its 95\% CI using both fixed-effects and random-effects models. ${ }^{8,9}$ We also estimated the $95 \%$ prediction interval, which further accounts for between-study heterogeneity and evaluates the uncertainty for the effect that would be expected in a new study addressing that same association. ${ }^{10,11}$ For the largest study of each meta-analysis, we estimated the SE of the effect size and we examined whether the SE was less than 0.1. In a study with SE of less than 0.1, the difference between the effect estimate and the upper or lower $95 \%$ confidence interval is less than 0.2 (i.e. this uncertainty is less than what is considered a small effect size).

In case of meta-analyses with continuous data, the effect estimate was transformed to an odds ratio with an established formula. ${ }^{12}$ Between-study heterogeneity was assessed via the $\mathrm{I}^{2}$ metric. ${ }^{13} \mathrm{I}^{2}$ ranges between $0 \%$ and $100 \%$ and is the ratio of between-study variance over the sum of the within- and between-study variances. ${ }^{14}$ Values exceeding $50 \%$ or $75 \%$ are usually considered to represent large or very large heterogeneity, respectively. The $95 \%$ CI of $\mathrm{I}^{2}$ estimates can be wide when there are few studies. ${ }^{15}$ 
We evaluated whether there was evidence for small-study effects (i.e. whether smaller studies tend to give substantially larger estimates of effect size compared with larger studies) ${ }^{16}$ using the regression asymmetry test proposed by Egger and colleagues. ${ }^{17} \mathrm{~A}$ $\mathrm{P}$ value less than 0.1 with more conservative effect in larger studies judged to be evidence for small-study effects.

We applied the excess statistical significance test, which evaluates whether the observed (O) number of studies with nominally statistically significant results ("positive" studies, $\mathrm{P}<0.05)$ is larger than their expected $(\mathrm{E})$ number. ${ }^{18} \mathrm{E}$ is calculated in each meta-analysis by the sum of the statistical power estimates for each component study. The true effect size for any meta-analysis is not known. We estimated the power of each component study using the effect size of the largest study (smallest SE) in a meta-analysis. ${ }^{19}$ The power of each study was calculated using a non-central $t$ distribution. ${ }^{20}$ Excess statistical significance for single meta-analyses was claimed at two-sided $\mathrm{P}<0.10$ with $\mathrm{O}>\mathrm{E}$ as previously proposed. ${ }^{18}$

For the meta-analyses ${ }^{21}$ on pesticides and well-water drinking, we used data from older meta-analyses ${ }^{22,23}$, because the largest one did not adequately report the data needed to perform our analyses. For the meta-analysis on diabetes mellitus, we extracted data from two different papers. ${ }^{24,25}$ The more recently published paper $^{25}$ reported data only from case-control studies and the older one ${ }^{24}$ included case-control and cohort studies, from which we kept cohort studies only and synthesized them with case-control studies from the recent paper. For two meta-analyses, pertaining to constipation $^{23}$ and gout ${ }^{26}$, we were not able to assess small-study effects and to estimate the $95 \%$ prediction interval, because only 2 observational studies were available for each meta-analysis. 
Finally, we identified putative risk factors that had the strongest statistical support for association $^{27,28}$ and no signals of high heterogeneity or bias. Specifically, we used the following categories: Highly convincing evidence required >1000 cases, highly statistically significant summary associations ( $\mathrm{p}<10^{-6}$ by random effects), no evidence of small-study effects, no evidence of excess significance bias, 95\% prediction interval not including the null and not large heterogeneity $\left(\mathrm{I}^{2}<50 \%\right)$. Highly suggestive evidence required $>1000$ cases, highly statistically significant summary associations ( $\mathrm{p}<10^{-6}$ by random effects) and largest study with $95 \%$ CI excluding the null. Suggestive evidence required only $>1000$ cases and $p<0.001$ by random effects. All other risk factors with nominally significant summary associations $(p<0.05)$ were coined as having weak evidence. Non-significant associations were those with $\mathrm{p}>0.05$.

Even when evidence for association is convincing or highly suggestive, this still does not prove causation. Therefore, in the Discussion, we explore systematically all putative risk factors with strong or highly suggestive evidence for association in terms of alternative explanations besides a causal relationship (reverse causation, residual confounding, information bias, sponsor conflicts or other caveats).

The statistical analysis and the power calculations were done with STATA version 12.0.

Role of the funding source

There was no funding source for this study. All authors had full access to all the study data. The corresponding author had final responsibility for the decision to submit for publication. 


\section{Results}

Overall, 884 articles were searched and 32 articles were eligible (figure). The eligible papers were published between 2005 and 2015 (median, 2013; IQR, 2012-2014). 21 articles were excluded in full text screening, because a larger meta-analysis was available. The aforementioned 21 articles examined smoking $(n=9),{ }^{29-37}$ pesticides $(\mathrm{n}=5),{ }^{38-42}$ physical activity $(\mathrm{n}=2),{ }^{43,44}$ coffee $(\mathrm{n}=3),{ }^{35,45,46}$ farming $(\mathrm{n}=1)^{39}$, aspirin $(n=1),{ }^{47}$ bone mineral density $(n=1),{ }^{48}$ fat intake $(n=1),{ }^{49}$ ibuprofen $(n=1),{ }^{47}$ tea $(\mathrm{n}=1),{ }^{45}$ and well water drinking $(\mathrm{n}=1)^{39}$. One $\operatorname{article}^{50}$ on body mass index was excluded due to inadequate data reporting.

The 32 articles correspond to 66 unique meta-analyses, including 691 primary observational studies as a whole. The median number of studies per meta-analysis was 7 (IQR 5-11) and the median number of cases was 1405 (IQR 677-4899). The 66 meta-analyses covered a wide range of risk factors categorized as biomarkers, dietary factors, drugs, exposure to toxic environmental agents, habits and medical history or comorbid diseases. The number of cases was greater than 1000 in 41 meta-analyses. All eligible meta-analyses used summary-level data from published literature and none of them had access to individual participant data. In 4 papers ${ }^{51-54}$ (7 metaanalyses) the effect size was expressed in weighted mean difference, which we transformed to standardized mean difference and then to OR. In 2 papers ${ }^{55,56}$ (6 metaanalyses) the summary effect size was expressed in standardized mean difference, which we transformed to OR.

Thirteen articles used the Newcastle-Ottawa Scale to qualitatively assess the included primary studies. Details are presented in table 4. Another article ${ }^{24}$ assessed the 
potential existence of bias in the case ascertainment and the selection bias. An additional article $^{52}$ used the QUADAS-2 for this assessment. Taking into account the methodological assessment of the primary observational studies performed by the eligible papers, almost half of the primary studies presented low methodological quality and were of high risk for bias, according to Newcastle-Ottawa scale.

$34(51 \%)$ of 66 meta-analyses reported effects that were significant at $p$ values less than 0.05 under the random-effects model. $20(30 \%)$ were significant at $p$ values less than 0.001 under the random-effects model: physical activity, ibuprofen, head injury, dairy products intake, welding, anxiety or depression, beta-blockers, coffee drinking, constipation, smoking, pesticides, nigral volume loss, gout, serum uric acid, retinal nerve fiber layer thickness, calcium channel blockers, rural living, farming, alcohol drinking and bone mineral density in lumbar spine. In seven of these (dairy products intake, welding, anxiety or depression, coffee drinking, smoking, physical activity and ibuprofen) the $95 \%$ prediction interval rule for random-effects model did not include the null. The remaining meta-analyses of risk factors had prediction intervals that included the null value, showing that, although on average these putative risk factors are associated with PD, this might not always be the case in specific settings (table 1).

The results of the largest study were more conservative than the summary result in 34 (52\%) meta-analyses (table 2$)$. However, the largest study was typically not very large or substantially different in weight from other studies. In 21 meta-analyses, the SE of the largest study was less than 0.10 in a $\log$ OR scale (it was $<0.20$ in 51 metaanalyses).

38 (58\%) meta-analyses had large heterogeneity estimates $\left(\mathrm{I}^{2} \geq 50 \%\right)$ and $19(29 \%)$ meta-analyses had very large heterogeneity estimates ( $\left.{ }^{2}>75 \%\right)$. Evidence for small- 
study effects was noted in $12(18 \%)$ meta-analyses. These meta-analyses pertained to alcohol drinking, coffee drinking, energy intake, exposure to hydrocarbons, serum vitamin D, lutein intake, non-aspirin NSAIDs, organic solvents, pesticides, rural living, statins, and smoking. Assuming that the effect size in the largest study was the true effect, $35(53 \%)$ of the 66 meta-analyses had a significant difference between the number of observed and expected positive studies (table 2).

Of the 66 meta-analyses, $15(23 \%)$ presented a significant association at $\mathrm{P}<10^{-6}$. Six risk factors, which include anxiety or depression ${ }^{23}$, beta-blockers ${ }^{23}$, head injury ${ }^{57}$, serum uric acid ${ }^{55}$, physical activity ${ }^{58}$ and smoking ${ }^{23}$, presented highly suggestive evidence ( $>1000$ cases, $\mathrm{p}<10^{-6}$ and largest study $95 \%$ CI excluding the null). However, all of these six risk factors had either large or very large heterogeneity $(n=3)$, or prediction interval including the null value $(n=3)$ or hints for small-study effects $(n=1)$ and/or excess significance bias $(n=2)$.

An overall summary assessment of the strength of the evidence for association of putative risk factors with Parkinson's disease is presented in table 3.

\section{Discussion}

We provide an overview and appraisal of environmental risk factors that have been associated with Parkinson's disease. Overall, 66 risk factors have been studied for an association with the disease, including biomarkers, dietary factors, drugs, exposure to toxic environmental agents, habits and medical history or comorbid diseases. Several putative risk factors (head injury, anxiety or depression, beta-blockers, smoking, physical activity, serum uric acid) had very low p-values $\left(<10^{-6}\right)$ and an effect was 
seen also in the largest study, but there was either large between-study heterogeneity and/or large uncertainty in the predictive interval and/or signals of bias.

The majority of the examined meta-analyses had large heterogeneity and some had signals of small-study effects or/and excess significance. The applied Egger test is particularly difficult to interpret when between-study heterogeneity is large. Heterogeneity might often be a manifestation of bias in some studies of a metaanalysis, but could also emerge from genuine differences across studies. Reasons for heterogeneity include the mixture of cohort studies and case-control studies in some of the meta-analyses, mixture of differences in exposure assessment, frequency of exposed in control groups, types of exposures and source of controls and differential response rates among cases and controls in the primary studies. The reported associations with disease need to be interpreted with caution, in particular for the meta-analyses in which the heterogeneity is large, the number of studies is relatively small, the largest study is more conservative than the summary effect, and small-study effects are evident.

The observed inverse association between physical activity and PD is further supported by animal and human laboratory studies. ${ }^{59,60}$ In animal models exposed to toxic compounds like MPTP, forced physical activity, spared nigrostriatal dopaminergic terminals and attenuated movement abnormalities. ${ }^{59}$ In humans, physical exercise has been suggested to increase plasma urate and uric acid levels, which in turn have been associated with lower risk for Parkinson's disease. ${ }^{58}$ However, an element of reverse causation cannot be totally excluded, since patients with pre-diagnosis of PD may exercise less because of the neurological dysfunction. ${ }^{61,62}$ Peripheral autonomic disorders in early stages of PD development may result in decreased cardiac chronotropic response during exercise and decrease 
the level of physical activity. Also, for the association of physical activity with PD, we found evidence for excess significance.

Among other putative risk factors, highly statistically significant associations were seen for increased risk with head injury, anxiety or depression, and beta-blockers, and for decreased risk with smoking and uric acid levels. In all of these factors, the largest study also showed a significant association signal. For smoking, the level of statistical significance for the association was extremely impressive $\left(\mathrm{P}=1.30 \times 10^{-37}\right.$ by random effects), but there were strong signals for small-study effects and for excess significance. This suggests that the literature on this risk factor is probably subjected to selective reporting and other biases and the summary effects may be exaggerated. A small protective effect for smoking is nevertheless likely to exist. However, it has also been argued that much, if not all, of the association effect with smoking may be explained by various biases, ${ }^{63}$ rather than the neuroprotective role of nicotine. ${ }^{64}$ First, there may be lack of information regarding PD diagnoses in the death certificates and medical records of smokers (information bias). Second, there may be selective mortality of smokers from causes other than PD, constituting a form of selection bias due to competing risk. If smokers die earlier than non-smokers from causes unrelated to PD, smokers may be under-represented among prevalent PD patients. Third, individuals with PD may be less prone to smoke or more prone to quit (reverse causation). ${ }^{63,65}$ Last, smoking and PD may share common covariates (confounding) not accounted for in the primary studies. For example, genetic factors may be associated with both an increased risk of PD and a higher likelihood of abstaining from smoking. ${ }^{63}$

Head trauma appeared to have a positive association with PD. According to a report by the International Collaboration on Mild Traumatic Brain Injury Prognosis, ${ }^{66}$ the 
epidemiological evidence supports that mild traumatic brain injury is not associated with PD. Reverse causality may operate here, because head injury result from imbalance which is an early sign of PD. ${ }^{67,68}$ Likewise, depression is probably best seen as a prodromal symptom of PD rather than a risk factor, because an early stage of PD is characterized by loss of serotonigergic neuronal cells in the dorsal raphe nucleus. ${ }^{69}$

Uric acid is thought to be a predictor of clinical progression of $\mathrm{PD} .{ }^{70}$ In agreement to that, the meta-analysis of the two cohort studies examining the association of gout, a disease characterized by high levels of serum uric acid, with PD showed a robust protective effect, but more studies are needed to assess the reproducibility of these findings. However, the meta-analysis for serum urate, a metabolite of serum uric acid, presented a significant association supported by weak evidence. Furthermore, an association between dairy products and PD was supported by suggestive evidence. This association can be attributed to the reduction of serum uric acid levels, which was also supported by evidence from the Third National Health and Nutrition Examination Survey. ${ }^{71}$

Degeneration of norepinephrine neurons in the locus coeruleus and deficits in norepinephrine are common findings in $\mathrm{PD}$, which could be aggravated by use of beta blockers and lead to PD. This is probably depicted in the modest harmful effect of beta-blockers. $^{72}$

The association between pesticides and PD had a modest effect and was supported by suggestive evidence. However, there was evidence for large heterogeneity, small study effects and excess significance, leading to an inflated effect size. Furthermore, farming and rural living (proxies of exposure to pesticides) presented a significant 
association with PD, but these associations were characterized by large heterogeneity and/or bias. Furthermore, organic solvents cause neurological problems and can hardly be considered specific dopaminergic toxins. The potential mechanism of action is damage of the basal ganglia. The mechanisms whereby these chemicals cause selective toxicity to these brain regions are not fully understood. ${ }^{73}$ Epidemiological studies on these exposures include different populations (occupational exposures or not), different thresholds of duration of exposure and different method of assessment of exposure (questionnaire or interview), so it is difficult to draw a safe conclusion. The large heterogeneity on the meta-analysis on pesticides and organic solvents could not be explained by the various chemical compounds that are included in these environmental exposures. The subgroup analysis performed per chemical compound either failed to show a statistically significant effect or preserved the large statistical heterogeneity, when the effect was significant.

Two other evaluated factors, coffee and alcohol, showed impressive P values in their summary effects, suggesting a protective impact on PD. However, for both of them, the largest study showed no effect and there was evidence for small-study effects and excess significance. This suggests that the observed associations may be due to bias. However, on the basis of the protective effect of coffee in $\mathrm{PD}$, adenosine receptor antagonists have been tested and there is some evidence that they improve parkinsonian symptoms in phase 2 clinical trials. ${ }^{74,75}$ An explanation for the observed inverse association between alcohol and PD may be residual confounding, possibly by smoking or coffee. ${ }^{64}$ Based on the Newcastle-Ottawa scale, two-thirds of the observational studies examining the association between alcohol and PD had low quality ratings. Moreover the finding that ibuprofen use, but not use of aspirin or other 
NSAIDs, could be associated with lower PD risk suggests mechanisms other than a generic anti-inflammatory activity of NSAIDs. ${ }^{76}$

PD diagnosis is based upon clinical criteria solely and symptoms arise after damage of at least $60 \%$ of dopaminergic substantia nigra cells. ${ }^{77}$ For that reason $\mathrm{PD}$ is quite often diagnosed in a stage of extensive damage, where neuroprotective agents fail to prevent any further damage. ${ }^{78,79}$ This is why the identification of a biomarker could be a breakthrough to help slow the progression of $\mathrm{PD}$, by recognizing it at an earlier, preclinical even, stage. However none of the meta-analyses on biomarkers showed unequivocal evidence for association with PD. All meta-analyses about the wide spectrum of biomarker either imaging or measured in CSF, plasma or serum, have large heterogeneity and a small sample size.

Our analysis has some caveats. Some of the caveats, pertaining to the interpretation of tests for statistical bias and the potentially effect inflation even in the largest studies, are applicable to all umbrella reviews of risk factors, as we have discussed on a previous umbrella review about risk factors for multiple sclerosis. ${ }^{6}$ We did not appraise the quality of the individual component primary studies, because this was beyond the scope of this umbrella review. This was the aim of the original systematic reviews and meta-analyses, which should include an assessment of study quality and whether the study should be included in the quantitative calculations. Indeed, some of the systematic reviews and meta-analyses applied the Newcastle-Ottawa scale to qualitatively appraise the observational studies, indicating almost half of these primary studies were of poor quality. Also, in our analysis we assessed only associations considered by meta-analyses of observational studies. Thus, we might miss other associations with adequate evidence that have not yet been assessed through meta-analytic approaches. Recently published cohort studies investigated the 
exposure to extremely low frequency magnetic fields ${ }^{80}$, zolpidem intake $e^{81}$, and the existence of end-stage renal disease ${ }^{82}$ as risk factors for developing PD, but these factors have not been studied in a published meta-analysis and were not addressed in our analysis. Finally, while we focus on biases and other issues that may have led to false-positive associations, false-negatives cannot be excluded also, especially for associations where limited evidence from small studies is available.

Acknowledging these caveats, our assessment maps the status of evidence on associations between environmental risk factors and risk for PD. A potential clinical implication of pinpointing the strong associations is the identification of high risk individuals for developing PD in order to run an organized screening program to detect preclinical stages of the disease. Such screening tests have already been proposed and include testing for non-motor prodromal symptoms i.e. hyposmia, constipation, depression, sleep disorders and apathy. ${ }^{79,83,84}$ Several associations have highly suggestive evidence, and fewer, if any, are likely to be causal, rather than confounded or the result of information biases or reverse causality. The mechanisms of several putative risk factors are not fully understood. Data from more studies and investigation of sources of heterogeneity are needed to better understand the association between these factors and PD. 


\section{References}

1 De Lau LML, Breteler MMB. Epidemiology of Parkinson's disease. Lancet Neurol 2006; 5: 525-35.

2 Pringsheim T, Jette N, Frolkis A, Steeves TDL. The prevalence of Parkinson's disease: A systematic review and meta-analysis. Mov Disord 2014; 29: 158390 .

3 Kowal SL, Dall TM, Chakrabarti R, Storm M V, Jain A. The current and projected economic burden of Parkinson's disease in the United States. Mov Disord 2013; 28: 311-8.

4 Klein C, Westenberger A. Genetics of Parkinson's disease. Cold Spring Harb Perspect Med 2012; 2: a008888.

5 Ioannidis JPA. Integration of evidence from multiple meta-analyses: a primer on umbrella reviews, treatment networks and multiple treatments metaanalyses. CMAJ 2009; 181: 488-93.

6 Belbasis L, Bellou V, Evangelou E, Ioannidis JPA, Tzoulaki I. Environmental risk factors and multiple sclerosis: an umbrella review of systematic reviews and meta-analyses. Lancet Neurol 2015; published online Feb. DOI:10.1016/S1474-4422(14)70267-4.

7 Nalls MA, Pankratz N, Lill CM, et al. Large-scale meta-analysis of genomewide association data identifies six new risk loci for Parkinson's disease. Nat Genet 2014; 46: 989-93.

8 DerSimonian R, Laird N. Meta-analysis in clinical trials. Control Clin Trials 1986; 7: 177-88.

9 Lau J, Ioannidis JP, Schmid CH. Quantitative synthesis in systematic reviews. Ann Intern Med 1997; 127: 820-6.

10 Higgins JPT, Thompson SG, Spiegelhalter DJ. A re-evaluation of randomeffects meta-analysis. J R Stat Soc Ser A Stat Soc 2009; 172: 137-59.

11 Higgins JPT. Commentary: Heterogeneity in meta-analysis should be expected and appropriately quantified. Int J Epidemiol 2008; 37: 1158-60.

12 Chinn S. A simple method for converting an odds ratio to effect size for use in meta-analysis. Stat Med 2000; 19: 3127-31.

13 Cochran WG. The Combination of Estimates from Different Experiments. Biometrics 1954; 10: 101.

14 Higgins JPT, Thompson SG. Quantifying heterogeneity in a meta-analysis. Stat Med 2002; 21: 1539-58. 
15 Ioannidis JPA, Patsopoulos NA, Evangelou E. Uncertainty in heterogeneity estimates in meta-analyses. $B M J$ 2007; 335: 914-6.

16 Sterne JAC, Sutton AJ, Ioannidis JPA, et al. Recommendations for examining and interpreting funnel plot asymmetry in meta-analyses of randomised controlled trials. $B M J$ 2011; 343: d4002.

17 Egger M, Davey Smith G, Schneider M, Minder C. Bias in meta-analysis detected by a simple, graphical test. BMJ 1997; 315: 629-34.

18 Ioannidis JPA, Trikalinos TA. An exploratory test for an excess of significant findings. Clin Trials 2007; 4: 245-53.

19 Ioannidis JPA. Clarifications on the application and interpretation of the test for excess significance and its extensions. J Math Psychol 2013; 57: 184-7.

20 Lubin JH, Gail MH. On power and sample size for studying features of the relative odds of disease. Am J Epidemiol 1990; 131: 552-66.

21 Pezzoli G, Cereda E. Exposure to pesticides or solvents and risk of Parkinson disease. Neurology 2013; 80: 2035-41.

22 Van der Mark M, Brouwer M, Kromhout H, Nijssen P, Huss A, Vermeulen R. Is pesticide use related to Parkinson disease? Some clues to heterogeneity in study results. Environ Health Perspect 2012; 120: 340-7.

23 Noyce AJ, Bestwick JP, Silveira-Moriyama L, et al. Meta-analysis of early nonmotor features and risk factors for Parkinson disease. Ann Neurol 2012; 72: 893-901.

24 Cereda E, Barichella M, Pedrolli C, et al. Diabetes and risk of Parkinson's disease: a systematic review and meta-analysis. Diabetes Care 2011; 34: 2614 23.

25 Lu L, Fu D-L, Li H-Q, Liu A-J, Li J-H, Zheng G-Q. Diabetes and risk of Parkinson's disease: an updated meta-analysis of case-control studies. PLoS One 2014; 9: e85781.

26 Shen C, Guo Y, Luo W, Lin C, Ding M. Serum urate and the risk of Parkinson's disease: results from a meta-analysis. Can J Neurol Sci 2013; 40: 73-9.

27 Ioannidis JPA, Tarone R, McLaughlin JK. The false-positive to false-negative ratio in epidemiologic studies. Epidemiology 2011; 22: 450-6.

28 Johnson VE. Revised standards for statistical evidence. Proc Natl Acad Sci US A 2013; 110: 19313-7.

29 Allam MF, Campbell MJ, Del Castillo AS, Fernández-Crehuet Navajas R. Parkinson's disease protects against smoking? Behav Neurol 2004; 15: 65-71. 
30 Allam MF, Campbell MJ, Hofman A, Del Castillo AS, Fernández-Crehuet Navajas R. Smoking and Parkinson's disease: systematic review of prospective studies. Mov Disord 2004; 19: 614-21.

31 Allam MF, del Castillo AS, Navajas RF-C. [Parkinson's disease, tobacco and age: meta analysis]. Rev Neurol; 36: 510-3.

32 Allam MF, Del Castillo AS, Navajas RF-C. Parkinson's disease, smoking and family history: meta-analysis. Eur J Neurol 2003; 10: 59-62.

33 Allam MF, Serrano del Castillo A, Fernández-Crehuet Navajas R. Smoking and Parkinson's disease: explanatory hypothesis. Int J Neurosci 2002; 112: $851-4$.

34 Ritz B, Ascherio A, Checkoway H, et al. Pooled analysis of tobacco use and risk of Parkinson disease. Arch Neurol 2007; 64: 990-7.

35 Hernán MA, Takkouche B, Caamaño-Isorna F, Gestal-Otero JJ. A metaanalysis of coffee drinking, cigarette smoking, and the risk of Parkinson's disease. Ann Neurol 2002; 52: 276-84.

36 Sugita M, Izuno T, Tatemichi M, Otahara Y. Meta-analysis for epidemiologic studies on the relationship between smoking and Parkinson's disease. $J$ Epidemiol 2001; 11: 87-94.

37 Kiyohara C, Kusuhara S. Cigarette smoking and Parkinson's disease: a metaanalysis. Fukuoka Igaku Zasshi 2011; 102: 254-65.

38 Allen MT, Levy LS. Parkinson's disease and pesticide exposure--a new assessment. Crit Rev Toxicol 2013; 43: 515-34.

39 Priyadarshi A, Khuder SA, Schaub EA, Priyadarshi SS. Environmental risk factors and Parkinson's disease: a metaanalysis. Environ Res 2001; 86: 122-7.

40 Priyadarshi A, Khuder SA, Schaub EA, Shrivastava S. A meta-analysis of Parkinson's disease and exposure to pesticides. Neurotoxicology 2000; 21: $435-40$.

41 Van Maele-Fabry G, Hoet P, Vilain F, Lison D. Occupational exposure to pesticides and Parkinson's disease: a systematic review and meta-analysis of cohort studies. Environ Int 2012; 46: 30-43.

42 Freire C, Koifman S. Pesticide exposure and Parkinson's disease: epidemiological evidence of association. Neurotoxicology 2012; 33: 947-71.

43 Hamer M, Chida Y. Physical activity and risk of neurodegenerative disease: a systematic review of prospective evidence. Psychol Med 2009; 39: 3-11.

$44 \mathrm{Xu}$ Q, Park Y, Huang X, et al. Physical activities and future risk of Parkinson disease. Neurology 2010; 75: 341-8. 
45 Costa J, Lunet N, Santos C, Santos J, Vaz-Carneiro A. Caffeine exposure and the risk of Parkinson's disease: a systematic review and meta-analysis of observational studies. J Alzheimers Dis 2010; 20 Suppl 1: S221-38.

46 Liu R, Guo X, Park Y, et al. Caffeine intake, smoking, and risk of Parkinson disease in men and women. Am J Epidemiol 2012; 175: 1200-7.

47 Samii A, Etminan M, Wiens MO, Jafari S. NSAID use and the risk of Parkinson's disease: systematic review and meta-analysis of observational studies. Drugs Aging 2009; 26: 769-79.

48 Torsney KM, Noyce AJ, Doherty KM, Bestwick JP, Dobson R, Lees AJ. Bone health in Parkinson's disease: a systematic review and meta-analysis. $J$ Neurol Neurosurg Psychiatry 2014; 85: 1159-66.

49 Kamel F, Goldman SM, Umbach DM, et al. Dietary fat intake, pesticide use, and Parkinson's disease. Parkinsonism Relat Disord 2014; 20: 82-7.

50 Van der Marck MA, Dicke HC, Uc EY, et al. Body mass index in Parkinson's disease: a meta-analysis. Parkinsonism Relat Disord 2012; 18: 263-7.

51 Lv Z, Qi H, Wang L, et al. Vitamin D status and Parkinson's disease: a systematic review and meta-analysis. Neurol Sci 2014; 35: 1723-30.

52 Gao L, Tang H, Nie K, et al. Cerebrospinal fluid alpha-synuclein as a biomarker for Parkinson's disease diagnosis: a systematic review and metaanalysis. Int J Neurosci 2014; published online Oct.

DOI:10.3109/00207454.2014.961454.

53 Zhao Y, Shen L, Ji H-F. Osteoporosis risk and bone mineral density levels in patients with Parkinson's disease: a meta-analysis. Bone 2013; 52: 498-505.

54 Yu J-G, Feng Y-F, Xiang Y, et al. Retinal nerve fiber layer thickness changes in Parkinson disease: a meta-analysis. PLoS One 2014; 9: e85718.

55 Shen L, Ji H-F. Low uric acid levels in patients with Parkinson's disease: evidence from meta-analysis. BMJ Open 2013; 3: e003620.

56 Mariani S, Ventriglia M, Simonelli I, et al. Fe and $\mathrm{Cu}$ do not differ in Parkinson's disease: a replication study plus meta-analysis. Neurobiol Aging 2013; 34: 632-3.

57 Jafari S, Etminan M, Aminzadeh F, Samii A. Head injury and risk of Parkinson disease: a systematic review and meta-analysis. Mov Disord 2013; 28: 1222-9.

58 Yang F, Trolle Lagerros Y, Bellocco R, et al. Physical activity and risk of Parkinson's disease in the Swedish National March Cohort. Brain 2015; 138: 269-75. 
59 Tillerson JL, Caudle WM, Reverón ME, Miller GW. Exercise induces behavioral recovery and attenuates neurochemical deficits in rodent models of Parkinson's disease. Neuroscience 2003; 119: 899-911.

60 Green HJ, Fraser IG. Differential effects of exercise intensity on serum uric acid concentration. Med Sci Sports Exerc 1988; 20: 55-9.

61 Tanner CM, Comella CL. When brawn benefits brain: physical activity and Parkinson's disease risk. Brain 2015; 138: 238-9.

62 Palma JA, Kaufmann H. Autonomic disorders predicting Parkinson's disease. Park Relat Disord 2014; 20. DOI:10.1016/S1353-8020(13)70024-5.

63 Wirdefeldt K, Adami H-O, Cole P, Trichopoulos D, Mandel J. Epidemiology and etiology of Parkinson's disease: a review of the evidence. Eur J Epidemiol 2011; 26 Suppl 1: S1-58.

64 Van der Mark M, Nijssen PCG, Vlaanderen J, et al. A case-control study of the protective effect of alcohol, coffee, and cigarette consumption on Parkinson disease risk: time-since-cessation modifies the effect of tobacco smoking. PLoS One 2014; 9: e95297.

65 Ritz B, Lee P-C, Lassen CF, Arah OA. Parkinson disease and smoking revisited: ease of quitting is an early sign of the disease. Neurology 2014; 83: 1396-402.

66 Marras C, Hincapié CA, Kristman VL, et al. Systematic review of the risk of parkinson's disease after mild traumatic brain injury: Results of the international collaboration on mild traumatic brain injury prognosis. Arch Phys Med Rehabil 2014; 95. DOI:10.1016/j.apmr.2013.08.298.

67 Gao X, Chen H, Schwarzschild MA, Logroscino G, Ascherio A. Perceived imbalance and risk of Parkinson's disease. Mov Disord 2008; 23: 613-6.

68 Rugbjerg K, Ritz B, Korbo L, Martinussen N, Olsen JH. Risk of Parkinson's disease after hospital contact for head injury: population based case-control study. BMJ 2008; 337: a2494.

69 Aarsland D, Påhlhagen S, Ballard CG, Ehrt U, Svenningsson P. Depression in Parkinson disease--epidemiology, mechanisms and management. Nat Rev Neurol 2012; 8: 35-47.

70 Ascherio A, LeWitt PA, Xu K, et al. Urate as a predictor of the rate of clinical decline in Parkinson disease. Arch Neurol 2009; 66: 1460-8.

71 Choi HK, Liu S, Curhan G. Intake of purine-rich foods, protein, and dairy products and relationship to serum levels of uric acid: the Third National Health and Nutrition Examination Survey. Arthritis Rheum 2005; 52: 283-9. 
72 Brichta L, Greengard P, Flajolet M. Advances in the pharmacological treatment of Parkinson's disease: targeting neurotransmitter systems. Trends Neurosci 2013; 36: 543-54.

73 Lock EA, Zhang J, Checkoway H. Solvents and Parkinson disease: a systematic review of toxicological and epidemiological evidence. Toxicol Appl Pharmacol 2013; 266: 345-55.

74 Hauser RA, Olanow CW, Kieburtz KD, et al. Tozadenant (SYN115) in patients with Parkinson's disease who have motor fluctuations on levodopa: a phase 2b, double-blind, randomised trial. Lancet Neurol 2014; 13: 767-76.

75 Hauser RA, Cantillon M, Pourcher E, et al. Preladenant in patients with Parkinson's disease and motor fluctuations: a phase 2, double-blind, randomised trial. Lancet Neurol 2011; 10: 221-9.

76 Gao X, Chen H, Schwarzschild MA, Ascherio A. Use of ibuprofen and risk of Parkinson disease. Neurology 2011; 76: 863-9.

77 Cheng H-C, Ulane CM, Burke RE. Clinical progression in Parkinson disease and the neurobiology of axons. Ann Neurol 2010; 67: 715-25.

78 Lang AE. In pursuit of prodromal Parkinson's disease. Lancet Neurol 2015; 14: $27-8$.

79 Schrag A, Horsfall L, Walters K, Noyce A, Petersen I. Prediagnostic presentations of Parkinson's disease in primary care: a case-control study. Lancet Neurol 2015; 14: 57-64.

80 Brouwer M, Koeman T, van den Brandt PA, et al. Occupational exposures and Parkinson's disease mortality in a prospective Dutch cohort. Occup Environ Med 2015; published online Feb. DOI:10.1136/oemed-2014-102209.

81 Huang H-C, Tsai C-H, Muo C-H, et al. Risk of Parkinson's disease following zolpidem use: a retrospective, population-based cohort study. J Clin Psychiatry 2015; 76: e104-10.

82 Wang I-K, Lin C-L, Wu Y-Y, et al. Increased risk of Parkinson's disease in patients with end-stage renal disease: a retrospective cohort study. Neuroepidemiology 2014; 42: 204-10.

83 Goldman SM. Environmental toxins and Parkinson's disease. Annu Rev Pharmacol Toxicol 2014; 54: 141-64.

84 Berg D, Godau J, Seppi K, et al. The PRIPS study: screening battery for subjects at risk for Parkinson's disease. Eur J Neurol 2013; 20: 102-8.

85 Zhang D, Jiang H, Xie J. Alcohol intake and risk of Parkinson's disease: a meta-analysis of observational studies. Mov Disord 2014; 29: 819-22. 
86 Li F-J, Ji H-F, Shen L. A meta-analysis of tea drinking and risk of Parkinson's disease. ScientificWorldJournal 2012; 2012: 923464.

87 Mortimer JA, Borenstein AR, Nelson LM. Associations of welding and manganese exposure with Parkinson disease: review and meta-analysis. Neurology 2012; 79: 1174-80.

88 Palin O, Herd C, Morrison KE, et al. Systematic review and meta-analysis of hydrocarbon exposure and the risk of Parkinson's disease. Parkinsonism Relat Disord 2015; 21: 243-8.

89 Etminan M, Gill SS, Samii A. Intake of vitamin E, vitamin C, and carotenoids and the risk of Parkinson's disease: a meta-analysis. Lancet Neurol 2005; 4: $362-5$.

90 Jiang W, Ju C, Jiang H, Zhang D. Dairy foods intake and risk of Parkinson's disease: a dose-response meta-analysis of prospective cohort studies. Eur $J$ Epidemiol 2014; 29: 613-9.

91 Takeda A, Nyssen OP, Syed A, Jansen E, Bueno-de-Mesquita B, Gallo V. Vitamin A and carotenoids and the risk of Parkinson's disease: a systematic review and meta-analysis. Neuroepidemiology 2014; 42: 25-38.

92 Wang A, Lin Y, Wu Y, Zhang D. Macronutrients intake and risk of Parkinson's disease: A meta-analysis. Geriatr Gerontol Int 2014; published online Aug. DOI:10.1111/ggi.12321.

93 Liu R, Gao X, Lu Y, Chen H. Meta-analysis of the relationship between Parkinson disease and melanoma. Neurology 2011; 76: 2002-9.

94 Gagne JJ, Power MC. Anti-inflammatory drugs and risk of Parkinson disease: a meta-analysis. Neurology 2010; 74: 995-1002.

95 Lang Y, Gong D, Fan Y. Calcium channel blocker use and risk of Parkinson's disease: a meta-analysis. Pharmacoepidemiol drug Saf 2015; 24: 559-66.

96 Undela K, Gudala K, Malla S, Bansal D. Statin use and risk of Parkinson's disease: a meta-analysis of observational studies. J Neurol 2013; 260: 158-65.

97 Wang P, Li J, Qiu S, Wen H, Du J. Hormone replacement therapy and Parkinson's disease risk in women: a meta-analysis of 14 observational studies. Neuropsychiatr Dis Treat 2015; 11: 59-66.

98 Chen J, Guan Z, Wang L, Song G, Ma B, Wang Y. Meta-analysis: overweight, obesity, and Parkinson's disease. Int J Endocrinol 2014; 2014: 203930.

99 Gudala K, Bansal D, Muthyala H. Role of serum cholesterol in Parkinson's disease: a meta-analysis of evidence. J Parkinsons Dis 2013; 3: 363-70. 
1

2

3

4

5

6

7

8

9

10

11

12

13

14

15

16

17

18

19

20

21

22

23

24

25

26

27

28

29

30

31

32

33

34

35

36

37

38

39

40

41

42

43

44

45

46

47

48

49

50

51

52

53

54

55

56

57

58

59

60
100 Sako W, Murakami N, Izumi Y, Kaji R. MRI can detect nigral volume loss in patients with Parkinson's disease: evidence from a meta-analysis. J Parkinsons Dis 2014; 4: 405-11. 
Figure. Flow chart of literature search for systematic reviews and meta-analyses published from inception until April 16, 2015.

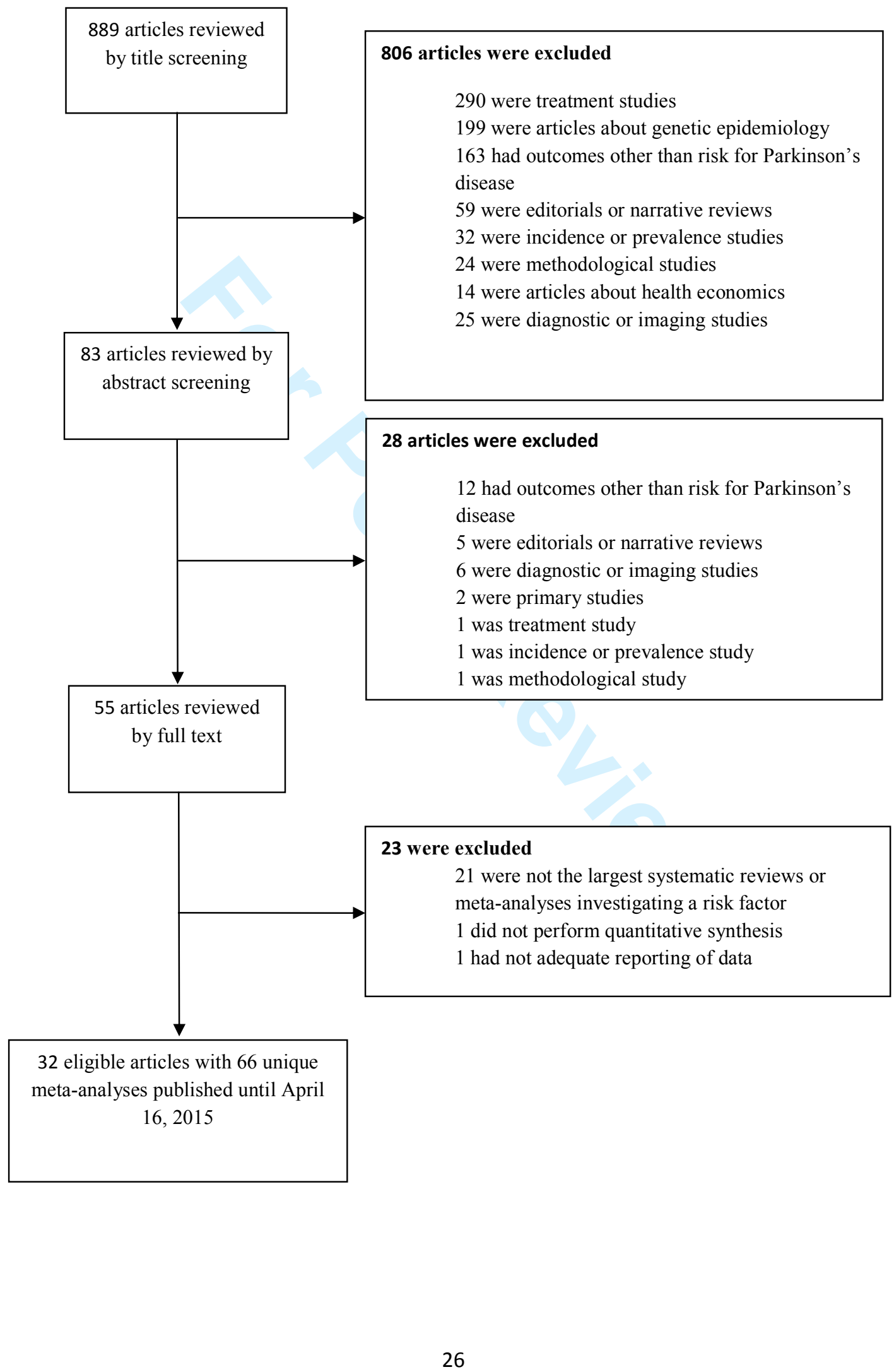


Table 1.Characteristics and quantitative synthesis of the 66 eligible meta-analyses of environmental risk factors for Parkinson's disease.

\begin{tabular}{|c|c|c|c|c|c|c|c|c|c|c|}
\hline Reference & Risk factor & $\begin{array}{l}\text { Level of } \\
\text { comparison }\end{array}$ & $\begin{array}{l}\text { Total } \\
\text { number of } \\
\text { Cases/Contr } \\
\text { ols }\end{array}$ & $\begin{array}{l}\text { Number } \\
\text { of } \\
\text { primary } \\
\text { studies } \\
\end{array}$ & $\begin{array}{l}\text { Effec } \\
\text { t size }\end{array}$ & $\begin{array}{l}\text { Random effects } \\
\text { summary effect } \\
\text { size }(95 \% \text { CI })\end{array}$ & $P$ random & 95\% PI & $\begin{array}{l}\text { Fixed effects } \\
\text { summary effect } \\
\text { size }(95 \% \text { CI })\end{array}$ & P fixed \\
\hline \multicolumn{11}{|l|}{ Habits } \\
\hline $\begin{array}{l}\text { Zhang, } \\
2014^{85}\end{array}$ & $\begin{array}{l}\text { Alcohol } \\
\text { intake }\end{array}$ & $\begin{array}{l}\text { High intake } \\
\text { vs. Low intake }\end{array}$ & $9994 / 667662$ & 33 & RR & $0.75(0.66-0.85)$ & $5.0 \times 10^{-6}$ & $0.44-1.25$ & $0.79(0.73-0.86)$ & $4.8 \times 10^{-9}$ \\
\hline $\begin{array}{l}\text { Noyce, } \\
2012^{23}\end{array}$ & $\begin{array}{l}\text { Coffee } \\
\text { drinking }\end{array}$ & $\begin{array}{l}\text { High intake } \\
\text { vs. Low intake }\end{array}$ & $5801 / 723072$ & 19 & RR & $0.67(0.58-0.76)$ & $3.4 \times 10^{-9}$ & $0.45-1.00$ & $0.72(0.65-0.78)$ & $1.5 \times 10^{-13}$ \\
\hline $\begin{array}{l}\text { Noyce, } \\
2012^{23}\end{array}$ & Smoking & $\begin{array}{l}\text { Exposed vs. } \\
\text { Non exposed }\end{array}$ & $\begin{array}{l}19537 / 10536 \\
45\end{array}$ & 67 & RR & $0.64(0.60-0.69)$ & $1.3 \times 10^{-37}$ & $0.45-0.92$ & $0.67(0.65-0.70)$ & $5.0 \times 10^{-77}$ \\
\hline $\mathrm{Li}, 2012^{86}$ & Tea drinking & $\begin{array}{l}\text { High intake } \\
\text { vs. Low intake }\end{array}$ & $1418 / 4250$ & 8 & OR & $0.86(0.68-1.08)$ & 0.197 & $0.45-1.62$ & $0.85(0.74-0.98)$ & 0.025 \\
\hline Yang, $2015^{58}$ & $\begin{array}{l}\text { Physical } \\
\text { activity }\end{array}$ & $\begin{array}{l}\text { High activity } \\
\text { vs. Low } \\
\text { activity }\end{array}$ & $1348 / 399959$ & 5 & HR & $0.66(0.57-0.78)$ & $3.0 \times 10^{-7}$ & $0.55-0.80$ & $0.66(0.57-0.78)$ & $3.0 \times 10^{-7}$ \\
\hline \multicolumn{11}{|c|}{ Exposure to toxic environmental agents } \\
\hline $\begin{array}{l}\text { Mortimer, } \\
2012^{87}\end{array}$ & $\begin{array}{l}\text { Manganese } \\
\text { exposure }\end{array}$ & $\begin{array}{l}\text { Exposed vs. } \\
\text { Non exposed }\end{array}$ & $1278 / 2762$ & 3 & $\mathrm{RR}$ & $0.76(0.41-1.42)$ & 0.392 & $0.001-661$ & $0.80(0.59-1.08)$ & 0.146 \\
\hline $\begin{array}{l}\text { Mortimer, } \\
2012^{87}\end{array}$ & Welding & Yes vs. No & $8198 / 572326$ & 9 & RR & $0.86(0.80-0.92)$ & $3.0 \times 10^{-5}$ & $0.79-0.94$ & $0.86(0.80-0.92)$ & $3.0 \times 10^{-5}$ \\
\hline Palin, $2015^{88}$ & $\begin{array}{l}\text { Hydrocarbon } \\
\text { exposure }\end{array}$ & $\begin{array}{l}\text { Exposed vs. } \\
\text { Non exposed }\end{array}$ & $4483 / 7179$ & 14 & OR & $1.36(1.13-1.63)$ & 0.001 & $0.88-2.08$ & $1.27(1.12-1.46)$ & $3.6 \times 10^{-4}$ \\
\hline $\begin{array}{l}\text { Pezzoli, } \\
2013^{21}\end{array}$ & Farming & $\begin{array}{l}\text { Exposed vs. } \\
\text { Non exposed }\end{array}$ & $\begin{array}{l}\text { 9533/ } \\
2303116\end{array}$ & 38 & OR & $1.30(1.16-1.46)$ & $5.7 \times 10^{-6}$ & $0.86-1.98$ & $1.29(1.19-1.39)$ & $6.7 \times 10^{-10}$ \\
\hline $\begin{array}{l}\text { Pezzoli, } \\
2013^{21}\end{array}$ & $\begin{array}{l}\text { Organic } \\
\text { solvents }\end{array}$ & $\begin{array}{l}\text { Exposed vs. } \\
\text { Non exposed }\end{array}$ & $3811 / 163859$ & 18 & OR & $1.22(1.01-1.47)$ & 0.036 & $0.72-2.08$ & $1.12(0.99-1.26)$ & 0.052 \\
\hline $\begin{array}{l}\text { van der } \\
\text { Mark, } 2012^{22}\end{array}$ & Pesticides & $\begin{array}{l}\text { Exposed vs. } \\
\text { Non exposed }\end{array}$ & $7151 / 292210$ & 39 & OR & $1.62(1.40-1.88)$ & $1.1 \times 10^{-10}$ & $0.81-3.23$ & $1.52(1.40-1.64)$ & $5.9 \times 10^{-26}$ \\
\hline Pezzoli, & Rural living & Exposed vs. & $4306 / 10009$ & 31 & OR & $1.32(1.18-1.48)$ & $1.7 \times 10^{-6}$ & $0.84-2.10$ & $1.01(0.99-1.02)$ & 0.363 \\
\hline
\end{tabular}




\begin{tabular}{|c|c|c|c|c|c|c|c|c|c|c|}
\hline $2013^{21}$ & & Non exposed & & & & & & & & \\
\hline $\begin{array}{l}\text { Noyce, } \\
2012^{23}\end{array}$ & $\begin{array}{l}\text { Well water } \\
\text { drinking }\end{array}$ & $\begin{array}{l}\text { Exposed vs. } \\
\text { Non exposed }\end{array}$ & $5037 / 8144$ & 28 & $\mathrm{RR}$ & $1.21(1.05-1.40)$ & 0.011 & $0.66-2.21$ & $0.99(0.95-1.04)$ & 0.735 \\
\hline \multicolumn{11}{|l|}{ Dietary factors } \\
\hline $\begin{array}{l}\text { Etminan, } \\
2005^{89}\end{array}$ & $\begin{array}{l}\text { Vitamin C } \\
\text { intake }\end{array}$ & $\begin{array}{l}\text { High intake } \\
\text { vs. Low intake }\end{array}$ & $1247 / 9214$ & 7 & OR & $1.06(0.86-1.30)$ & 0.602 & $0.64-1.74$ & $1.00(0.87-1.16)$ & 0.976 \\
\hline $\begin{array}{l}\text { Etminan, } \\
2005^{89}\end{array}$ & $\begin{array}{l}\text { Vitamin E } \\
\text { intake }\end{array}$ & $\begin{array}{l}\text { High intake } \\
\text { vs. Low intake }\end{array}$ & $936 / 7230$ & 7 & OR & $0.81(0.67-0.98)$ & 0.028 & $0.63-1.04$ & $0.81(0.67-0.98)$ & 0.028 \\
\hline Jiang, $2014^{90}$ & $\begin{array}{l}\text { Dairy } \\
\text { products } \\
\text { intake } \\
\end{array}$ & $\begin{array}{l}\text { High intake } \\
\text { vs. Low intake }\end{array}$ & $1083 / 310118$ & 7 & RR & $1.40(1.20-1.63)$ & $2.4 \times 10^{-5}$ & $1.08-1.81$ & $1.39(1.21-1.61)$ & $5.7 \times 10^{-6}$ \\
\hline $\begin{array}{l}\text { Takeda, } \\
2014^{91}\end{array}$ & $\begin{array}{l}\text { Lutein } \\
\text { intake }\end{array}$ & $\begin{array}{l}\text { High intake } \\
\text { vs. Low intake }\end{array}$ & $804 / 124720$ & 4 & OR & $1.49(0.83-2.68)$ & 0.179 & $0.12-18.65$ & $1.15(0.90-1.46)$ & 0.267 \\
\hline $\begin{array}{l}\text { Takeda, } \\
2014^{91}\end{array}$ & $\begin{array}{l}\text { Lycopene } \\
\text { intake }\end{array}$ & $\begin{array}{l}\text { High intake } \\
\text { vs. Low intake }\end{array}$ & $678 / 124288$ & 3 & OR & $1.03(0.64-1.65)$ & 0.896 & $0.01-174$ & $1.02(0.79-1.31)$ & 0.900 \\
\hline $\begin{array}{l}\text { Takeda, } \\
2014^{91}\end{array}$ & $\begin{array}{l}\text { Vitamin A } \\
\text { intake }\end{array}$ & $\begin{array}{l}\text { High intake } \\
\text { vs. Low intake }\end{array}$ & $624 / 2908$ & 3 & OR & $1.09(0.84-1.42)$ & 0.520 & $0.20-5.96$ & $1.09(0.84-1.42)$ & 0.520 \\
\hline $\begin{array}{l}\text { Takeda, } \\
2014^{91}\end{array}$ & $\begin{array}{l}\alpha \text {-carotene } \\
\text { intake }\end{array}$ & $\begin{array}{l}\text { High intake } \\
\text { vs. Low intake }\end{array}$ & $677 / 124268$ & 3 & OR & $0.84(0.59-1.18)$ & 0.313 & $0.04-16.60$ & $0.84(0.64-1.11)$ & 0.221 \\
\hline $\begin{array}{l}\text { Takeda, } \\
2014^{91}\end{array}$ & $\begin{array}{l}\beta \text {-carotene } \\
\text { intake }\end{array}$ & $\begin{array}{l}\text { High intake } \\
\text { vs. Low intake }\end{array}$ & $1395 / 125430$ & 6 & OR & $0.92(0.70-1.20)$ & 0.521 & $0.46-1.81$ & $0.92(0.75-1.13)$ & 0.417 \\
\hline $\begin{array}{l}\text { Takeda, } \\
2014^{91}\end{array}$ & $\begin{array}{l}\beta- \\
\text { cryptoxanthi } \\
n \text { intake }\end{array}$ & $\begin{array}{l}\text { High intake } \\
\text { vs. Low intake }\end{array}$ & $677 / 124268$ & 3 & OR & $0.96(0.66-1.40)$ & 0.834 & $0.02-39.43$ & $0.90(0.69-1.16)$ & 0.411 \\
\hline $\begin{array}{l}\text { Wang, } \\
2014^{92} \\
\end{array}$ & $\begin{array}{l}\text { Carbohydrat } \\
\text { e intake }\end{array}$ & $\begin{array}{l}\text { High intake } \\
\text { vs. Low intake }\end{array}$ & $1482 / 231387$ & 8 & RR & $1.24(1.05-1.48)$ & 0.014 & $1.00-1.54$ & $1.24(1.05-1.48)$ & 0.014 \\
\hline $\begin{array}{l}\text { Wang, } \\
2014^{92}\end{array}$ & $\begin{array}{l}\text { Cholesterol } \\
\text { intake }\end{array}$ & $\begin{array}{l}\text { High intake } \\
\text { vs. Low intake }\end{array}$ & $1293 / 168218$ & 7 & RR & $0.97(0.75-1.26)$ & 0.833 & $0.46-2.07$ & $0.91(0.79-1.05)$ & 0.211 \\
\hline $\begin{array}{l}\text { Wang, } \\
2014^{92}\end{array}$ & $\begin{array}{l}\text { Energy } \\
\text { intake }\end{array}$ & $\begin{array}{l}\text { High intake } \\
\text { vs. Low intake }\end{array}$ & $1415 / 168643$ & 8 & RR & $1.39(1.01-1.92)$ & 0.042 & $0.50-3.90$ & $0.99(0.95-1.03)$ & 0.607 \\
\hline $\begin{array}{l}\text { Wang, } \\
2014^{92}\end{array}$ & $\begin{array}{l}\text { Protein } \\
\text { intake }\end{array}$ & $\begin{array}{l}\text { High intake } \\
\text { vs. Low intake }\end{array}$ & $1570 / 356257$ & 7 & RR & $1.13(0.88-1.44)$ & 0.339 & $0.65-1.97$ & $1.15(0.95-1.39)$ & 0.151 \\
\hline $\begin{array}{l}\text { Wang, } \\
2014^{92} \\
\end{array}$ & $\begin{array}{l}\text { Total fat } \\
\text { intake }\end{array}$ & $\begin{array}{l}\text { High intake } \\
\text { vs. Low intake }\end{array}$ & $2516 / 370628$ & 13 & $\mathrm{RR}$ & $0.88(0.74-1.06)$ & 0.182 & $0.56-1.40$ & $0.86(0.75-0.98)$ & 0.024 \\
\hline
\end{tabular}




\begin{tabular}{|c|c|c|c|c|c|c|c|c|c|c|}
\hline \multicolumn{11}{|c|}{ Medical history and comorbid diseases } \\
\hline $\begin{array}{l}\text { Cereda, } \\
2011^{24} \text { and } \\
\mathrm{Lu}, 2014^{25}\end{array}$ & $\begin{array}{l}\text { Diabetes } \\
\text { mellitus }\end{array}$ & $\begin{array}{l}\text { Diseased vs. } \\
\text { Non diseased }\end{array}$ & $10743 / 54709$ & 6 & OR & $1.13(0.73-1.76)$ & 0.591 & $0.42-3.03$ & $1.24(0.93-1.65)$ & 0.143 \\
\hline $\begin{array}{l}\text { Jafari, } \\
2013^{57}\end{array}$ & Head injury & $\begin{array}{l}\text { Exposed vs. } \\
\text { Non exposed }\end{array}$ & $\begin{array}{l}35799 / 17264 \\
7\end{array}$ & 22 & OR & $1.55(1.33-1.81)$ & $2.2 \times 10^{-8}$ & $0.93-2.58$ & $1.56(1.45-1.67)$ & $3.5 \times 10^{-35}$ \\
\hline Liu, $2011^{93}$ & Melanoma & $\begin{array}{l}\text { Diseased vs. } \\
\text { Non diseased }\end{array}$ & $10743 / 54709$ & 6 & OR & $1.13(0.73-1.76)$ & 0.591 & $0.42-3.03$ & $1.24(0.93-1.65)$ & 0.143 \\
\hline $\begin{array}{l}\text { Noyce, } \\
2012^{23}\end{array}$ & $\begin{array}{l}\text { Anxiety or } \\
\text { Depression }\end{array}$ & $\begin{array}{l}\text { Diseased vs. } \\
\text { Non diseased }\end{array}$ & $\begin{array}{l}16211 / 16396 \\
57\end{array}$ & 13 & RR & $1.86(1.64-2.10)$ & $2.6 \times 10^{-22}$ & $1.30-2.66$ & $1.84(1.78-1.91)$ & $5.8 \times 10^{-258}$ \\
\hline $\begin{array}{l}\text { Noyce, } \\
2012^{23}\end{array}$ & Cancer & $\begin{array}{l}\text { Diseased vs. } \\
\text { Non diseased }\end{array}$ & $9693 / 34173$ & 7 & RR & $0.89(0.72-1.10)$ & 0.265 & $0.51-1.53$ & $1.01(0.94-1.09)$ & 0.777 \\
\hline $\begin{array}{l}\text { Noyce, } \\
2012^{23}\end{array}$ & Constipation & $\begin{array}{l}\text { Diseased vs. } \\
\text { Non diseased }\end{array}$ & $292 / 6890$ & 2 & RR & $2.34(1.55-3.53)$ & $5.5 \times 10^{-5}$ & $\mathrm{NE}$ & $2.34(1.55-3.53)$ & $5.5 \times 10^{-5}$ \\
\hline $\begin{array}{l}\text { Noyce, } \\
2012^{23}\end{array}$ & Gastric ulcer & $\begin{array}{l}\text { Diseased vs. } \\
\text { Non diseased }\end{array}$ & $406 / 661$ & 3 & RR & $1.37(0.36-5.31)$ & 0.646 & $\begin{array}{l}1.4 \times 10^{-7}- \\
1.4 \times 10^{7}\end{array}$ & $0.81(0.49-1.34)$ & 0.413 \\
\hline $\begin{array}{l}\text { Noyce, } \\
2012^{23}\end{array}$ & $\begin{array}{l}\text { Hypertensio } \\
\mathrm{n}\end{array}$ & $\begin{array}{l}\text { Diseased vs. } \\
\text { Non diseased }\end{array}$ & $5993 / 187226$ & 12 & RR & $0.75(0.61-0.90)$ & 0.003 & $0.40-1.40$ & $0.81(0.75-0.87)$ & $3.2 \times 10^{-8}$ \\
\hline $\begin{array}{l}\text { Noyce, } \\
2012^{23}\end{array}$ & $\begin{array}{l}\text { Oophorecto } \\
\text { my }\end{array}$ & Yes vs. No & $775 / 122149$ & 5 & RR & $0.77(0.52-1.13)$ & 0.180 & $0.23-2.60$ & $0.76(0.61-0.94)$ & 0.011 \\
\hline Shen, $2013^{26}$ & Gout & $\begin{array}{l}\text { Diseased vs. } \\
\text { Non diseased }\end{array}$ & $2234 / 72909$ & 2 & OR & $0.70(0.60-0.82)$ & $5.1 \times 10^{-6}$ & $\mathrm{NE}$ & $0.70(0.60-0.82)$ & $5.1 \times 10^{-6}$ \\
\hline \multicolumn{11}{|l|}{ Drugs } \\
\hline $\begin{array}{l}\text { Gagne, } \\
2010^{94}\end{array}$ & Aspirin & $\begin{array}{l}\text { Exposed vs. } \\
\text { Non exposed }\end{array}$ & $2781 / 296525$ & 6 & RR & $1.08(0.93-1.27)$ & 0.315 & $0.71-1.66$ & $1.12(1.01-1.24)$ & 0.027 \\
\hline $\begin{array}{l}\text { Gagne, } \\
2010^{94}\end{array}$ & $\begin{array}{l}\text { Non-aspirin } \\
\text { NSAIDs }\end{array}$ & $\begin{array}{l}\text { Exposed vs. } \\
\text { Non exposed }\end{array}$ & $3967 / 297453$ & 7 & RR & $0.85(0.77-0.94)$ & 0.002 & $0.74-0.97$ & $0.85(0.77-0.94)$ & 0.002 \\
\hline Gao, $2011^{76}$ & $\begin{array}{l}\text { Acetaminop } \\
\text { hen }\end{array}$ & $\begin{array}{l}\text { Exposed vs. } \\
\text { Non exposed }\end{array}$ & $2086 / 295660$ & 4 & RR & $1.09(0.96-1.24)$ & 0.192 & $0.82-1.45$ & $1.09(0.96-1.24)$ & 0.192 \\
\hline Gao, $2011^{76}$ & $\begin{array}{l}\text { Ibuprofen } \\
\text { use }\end{array}$ & $\begin{array}{l}\text { Exposed vs. } \\
\text { Non exposed }\end{array}$ & $2170 / 296165$ & 5 & RR & $0.73(0.62-0.85)$ & $6.6 \times 10^{-5}$ & $0.57-0.94$ & $0.73(0.62-0.85)$ & $6.6 \times 10^{-5}$ \\
\hline $\begin{array}{l}\text { Noyce, } \\
2012^{23}\end{array}$ & $\begin{array}{l}\text { Beta- } \\
\text { blockers }\end{array}$ & $\begin{array}{l}\text { Exposed vs. } \\
\text { Non exposed }\end{array}$ & $5774 / 13671$ & 3 & RR & $1.28(1.19-1.39)$ & $5.0 \times 10^{-10}$ & $0.77-2.13$ & $1.28(1.19-1.39)$ & $5.0 \times 10^{-10}$ \\
\hline Lang, $2015^{95}$ & $\begin{array}{l}\text { Calcium } \\
\text { channel }\end{array}$ & $\begin{array}{l}\text { Exposed vs. } \\
\text { Non exposed }\end{array}$ & $\begin{array}{l}6966 / 274947 \\
5\end{array}$ & 5 & RR & $0.78(0.67-0.90)$ & $7.0 \times 10^{-4}$ & $0.55-1.11$ & $0.76(0.68-0.84)$ & $1.4 \times 10^{-7}$ \\
\hline
\end{tabular}




\begin{tabular}{|c|c|c|c|c|c|c|c|c|c|c|}
\hline & blockers & & & & & & & & & \\
\hline $\begin{array}{l}\text { Noyce, } \\
2012^{23}\end{array}$ & $\begin{array}{l}\text { General } \\
\text { anesthesia }\end{array}$ & $\begin{array}{l}\text { Exposed vs. } \\
\text { Non exposed }\end{array}$ & $1571 / 3110$ & 6 & RR & $1.10(0.77-1.58)$ & 0.601 & $0.35-3.51$ & $0.93(0.80-1.09)$ & 0.364 \\
\hline $\begin{array}{l}\text { Noyce, } \\
2012^{23}\end{array}$ & $\begin{array}{l}\text { Oral } \\
\text { contraceptiv } \\
\text { es }\end{array}$ & $\begin{array}{l}\text { Exposed vs. } \\
\text { Non exposed }\end{array}$ & $572 / 121946$ & 3 & RR & $0.73(0.43-1.25)$ & 0.250 & $0.002-346$ & $0.86(0.68-1.09)$ & 0.215 \\
\hline $\begin{array}{l}\text { Undela, } \\
2013^{96}\end{array}$ & Statins & $\begin{array}{l}\text { Exposed vs. } \\
\text { Non exposed }\end{array}$ & $\begin{array}{l}15102 / 26188 \\
36\end{array}$ & 8 & RR & $0.77(0.64-0.92)$ & 0.004 & $0.47-1.27$ & $0.86(0.79-0.94)$ & 0.001 \\
\hline $\begin{array}{l}\text { Wang, } \\
2014^{97}\end{array}$ & $\begin{array}{l}\text { Hormone } \\
\text { Replacement } \\
\text { Therapy }\end{array}$ & $\begin{array}{l}\text { Exposed vs. } \\
\text { Non exposed }\end{array}$ & $4035 / 808830$ & 14 & RR & $1.00(0.84-1.20)$ & 0.967 & $0.61-1.64$ & $1.10(1.00-1.22)$ & 0.064 \\
\hline \multicolumn{11}{|l|}{ Biomarkers } \\
\hline Chen, $2014^{98}$ & BMI & $\begin{array}{l}\mathrm{BMI} \geq 30 \text { vs. } \\
\mathrm{BMI}<25\end{array}$ & $\begin{array}{l}1668 / 388253 \\
5\end{array}$ & 7 & OR & $0.96(0.61-1.50)$ & 0.854 & $0.20-4.62$ & $1.15(1.01-1.31)$ & 0.040 \\
\hline Chen, $2014^{98}$ & BMI & $\begin{array}{l}\mathrm{BMI} \geq 30 \text { vs. } \\
25 \bullet \mathrm{BMI}<30\end{array}$ & $\begin{array}{l}1618 / 243008 \\
8\end{array}$ & 7 & OR & $0.83(0.65-1.07)$ & 0.157 & $0.37-1.85$ & $0.89(0.78-1.01)$ & 0.061 \\
\hline Chen, $2014^{98}$ & BMI & $\begin{array}{l}25 \bullet \mathrm{BMI}<30 \\
\text { vs. } \mathrm{BMI}<25\end{array}$ & $\begin{array}{l}2428 / 505848 \\
4\end{array}$ & 7 & OR & $1.20(0.94-1.53)$ & 0.148 & $0.53-2.69$ & $1.28(1.18-1.40)$ & $1.3 \times 10^{-8}$ \\
\hline Gao, $2014^{52}$ & $\begin{array}{l}\alpha \text {-synuclein } \\
\text { in CSF }\end{array}$ & $\begin{array}{l}\text { High vs. Low } \\
\text { values }\end{array}$ & $850 / 589$ & 11 & OR & $0.29(0.13-0.62)$ & 0.002 & $0.02-5.19$ & $0.48(0.38-0.59)$ & $4.9 \times 10^{-12}$ \\
\hline $\begin{array}{l}\text { Gudala, } \\
2013^{99}\end{array}$ & $\begin{array}{l}\text { Serum } \\
\text { cholesterol }\end{array}$ & $\begin{array}{l}\text { High vs. Low } \\
\text { values }\end{array}$ & $5488 / 240624$ & 8 & RR & $0.91(0.71-1.15)$ & 0.418 & $0.44-1.86$ & $1.00(0.90-1.12)$ & 0.985 \\
\hline $\mathrm{Lv}, 2014^{51}$ & $\begin{array}{l}\text { Serum } \\
\text { vitamin D }\end{array}$ & $\begin{array}{l}\text { High vs. Low } \\
\text { values }\end{array}$ & $1008 / 4536$ & 7 & OR & $0.16(0.05-0.50)$ & 0.002 & $\begin{array}{l}0.003- \\
10.09\end{array}$ & $0.40(0.34-0.47)$ & $9.0 \times 10^{-29}$ \\
\hline $\begin{array}{l}\text { Mariani, } \\
2013^{56}\end{array}$ & $\begin{array}{l}\text { Copper in } \\
\text { plasma }\end{array}$ & $\begin{array}{l}\text { High vs. Low } \\
\text { values }\end{array}$ & $202 / 239$ & 4 & OR & $1.41(0.03-59.27)$ & 0.856 & $\begin{array}{l}1.7 \times 10^{-8}- \\
1.2 \times 10^{8}\end{array}$ & $3.47(2.29-5.24)$ & $3.6 \times 10^{-9}$ \\
\hline $\begin{array}{l}\text { Mariani, } \\
2013^{56}\end{array}$ & $\begin{array}{l}\text { Copper in } \\
\text { CSF }\end{array}$ & $\begin{array}{l}\text { High vs. Low } \\
\text { values }\end{array}$ & $215 / 119$ & 5 & OR & $2.06(0.57-7.44)$ & 0.271 & $0.02-207.2$ & $1.70(1.06-2.75)$ & 0.029 \\
\hline $\begin{array}{l}\text { Mariani, } \\
2013^{56}\end{array}$ & $\begin{array}{l}\text { Serum } \\
\text { copper }\end{array}$ & $\begin{array}{l}\text { High vs. Low } \\
\text { values }\end{array}$ & $425 / 333$ & 9 & OR & $1.46(0.46-4.63)$ & 0.519 & $0.02-94.65$ & $1.47(1.08-1.99)$ & 0.013 \\
\hline $\begin{array}{l}\text { Mariani, } \\
2013^{56}\end{array}$ & Iron in CSF & $\begin{array}{l}\text { High vs. Low } \\
\text { values }\end{array}$ & $215 / 119$ & 5 & OR & $0.93(0.35-2.45)$ & 0.887 & $0.03-30.86$ & $0.86(0.56-1.32)$ & 0.494 \\
\hline $\begin{array}{l}\text { Mariani, } \\
2013^{56}\end{array}$ & Serum iron & $\begin{array}{l}\text { High vs. Low } \\
\text { values }\end{array}$ & $520 / 711$ & 10 & OR & $0.45(0.17-1.17)$ & 0.102 & $0.01-16.71$ & $0.41(0.32-0.51)$ & $2.5 \times 10^{-14}$ \\
\hline
\end{tabular}




\begin{tabular}{|c|c|c|c|c|c|c|c|c|c|c|}
\hline $\begin{array}{l}\text { Sako, } \\
2014^{100}\end{array}$ & $\begin{array}{l}\text { Nigral } \\
\text { volume loss }\end{array}$ & $\begin{array}{l}\text { High vs. Low } \\
\text { values }\end{array}$ & $193 / 172$ & 8 & OR & $0.31(0.17-0.55)$ & $8.3 \times 10^{-5}$ & $0.06-1.46$ & $0.30(0.20-0.44)$ & $1.6 \times 10^{-9}$ \\
\hline Shen, $2013^{26}$ & Serum urate & $\begin{array}{l}\text { High vs. Low } \\
\text { values }\end{array}$ & $594 / 32591$ & 6 & RR & $0.65(0.43-0.97)$ & 0.034 & $0.23-1.82$ & $0.68(0.50-0.91)$ & 0.009 \\
\hline Shen, $2013^{55}$ & $\begin{array}{l}\text { Serum uric } \\
\text { acid }\end{array}$ & $\begin{array}{l}\text { High vs. Low } \\
\text { values }\end{array}$ & $1217 / 1276$ & 6 & OR & $0.39(0.27-0.57)$ & $6.8 \times 10^{-7}$ & $0.13-1.22$ & $0.33(0.29-0.38)$ & $1.1 \times 10^{-49}$ \\
\hline $\mathrm{Yu}, 2014^{54}$ & RNFLT & $\begin{array}{l}\text { High vs. Low } \\
\text { values }\end{array}$ & $644 / 604$ & 13 & OR & $0.40(0.24-0.66)$ & $3.5 \times 10^{-4}$ & $0.06-2.55$ & $0.39(0.32-0.49)$ & $1.7 \times 10^{-18}$ \\
\hline Zhao, $2013^{53}$ & $\begin{array}{l}\text { BMD in } \\
\text { femoral neck }\end{array}$ & $\begin{array}{l}\text { High vs. Low } \\
\text { values }\end{array}$ & $561 / 8800$ & 8 & OR & $0.25(0.09-0.66)$ & 0.005 & $0.01-8.76$ & $0.36(0.30-0.44)$ & $3.4 \times 10^{-24}$ \\
\hline Zhao, $2013^{53}$ & BMD in hip & $\begin{array}{l}\text { High vs. Low } \\
\text { values }\end{array}$ & $401 / 8654$ & 6 & OR & $0.55(0.38-0.80)$ & 0.002 & $0.18-1.66$ & $0.60(0.49-0.75)$ & $3.2 \times 10^{-6}$ \\
\hline Zhao, $2013^{53}$ & $\begin{array}{l}\text { BMD in } \\
\text { lumbar spine }\end{array}$ & $\begin{array}{l}\text { High vs. Low } \\
\text { values }\end{array}$ & $611 / 962$ & 9 & OR & $0.29(0.16-0.54)$ & $7.8 \times 10^{-5}$ & $0.03-2.60$ & $0.30(0.25-0.37)$ & $1.4 \times 10^{-32}$ \\
\hline Zhao, $2013^{53}$ & $\begin{array}{l}\text { BMD in } \\
\text { trochanter }\end{array}$ & $\begin{array}{l}\text { High vs. Low } \\
\text { values }\end{array}$ & $249 / 550$ & 4 & OR & $0.73(0.48-1.11)$ & 0.146 & $0.16-3.34$ & $0.75(0.57-0.99)$ & 0.044 \\
\hline
\end{tabular}

BMD: bone mineral density, BMI: body mass index, CI: confidence interval, CSF: cerebrospinal fluid, HR: hazard ratio, NSAIDs: non-steroidal anti-inflammatory drugs, NE: not estimable, OR: odds ratio, PI: prediction interval, RR: risk ratio, RNFLT: retinal nerve fiber layer thickness 
Table 2. Bias assessment of the 66 eligible meta-analyses of environmental risk factors for Parkinson's disease.

\begin{tabular}{|c|c|c|c|c|c|c|c|c|c|}
\hline \multirow[t]{2}{*}{ Reference } & \multirow[t]{2}{*}{ Risk factor } & \multirow{2}{*}{$\begin{array}{c}\text { Effect } \\
\text { size }\end{array}$} & \multicolumn{2}{|c|}{ Largest study } & \multirow[t]{2}{*}{$\mathbf{I}^{2}$} & \multirow{2}{*}{$\begin{array}{l}\text { Egger test } \\
\text { p-value }\end{array}$} & \multirow{2}{*}{\begin{tabular}{|c|} 
Observed \\
significant \\
studies
\end{tabular}} & \multirow{2}{*}{$\begin{array}{c}\text { Expected } \\
\text { significant } \\
\text { studies }\end{array}$} & \multirow{2}{*}{$\begin{array}{c}\text { Excess } \\
\text { significance } \\
\text { test p-value }\end{array}$} \\
\hline & & & $\begin{array}{c}\text { Effect size }(95 \% \\
\text { CI) }\end{array}$ & SE & & & & & \\
\hline \multicolumn{10}{|l|}{ Habits } \\
\hline Zhang, $2014^{85}$ & Alcohol intake & RR & $1.01(0.83-1.23)$ & 0.100 & 52.3 & 0.060 & 7 & 1.65 & $2.0 \times 10^{-5}$ \\
\hline Noyce, $2012^{23}$ & Coffee drinking & RR & $0.85(0.70-1.03)$ & 0.099 & 42.9 & 0.002 & 8 & 1.66 & $2.6 \times 10^{-7}$ \\
\hline Noyce, $2012^{23}$ & Smoking & RR & $0.74(0.67-0.82)$ & 0.052 & 49.6 & 0.018 & 39 & 10.50 & $<1.0 \times 10^{-8}$ \\
\hline $\mathrm{Li}, 2012^{86}$ & Tea drinking & OR & $0.91(0.73-1.12)$ & 0.110 & 53.0 & 0.758 & 2 & 0.46 & 0.019 \\
\hline Yang, $2015^{58}$ & Physical activity & HR & $0.68(0.51-0.90)$ & 0.145 & 0 & 0.556 & 4 & 1.83 & 0.072 \\
\hline \multicolumn{10}{|c|}{ Exposure to toxic environmental agents } \\
\hline Mortimer, $2012^{87}$ & Manganese exposure & RR & $0.92(0.64-1.32)$ & 0.185 & 62 & 0.935 & 1 & 0.19 & 0.053 \\
\hline Mortimer, $2012^{87}$ & Welding & RR & $0.85(0.77-0.94)$ & 0.051 & 0 & 0.221 & 2 & 1.52 & 0.670 \\
\hline Palin, $2015^{88}$ & Hydrocarbon exposure & OR & $1.06(0.86-1.30)$ & 0.105 & 28.1 & 0.020 & 5 & 0.75 & $4.5 \times 10^{-7}$ \\
\hline Pezzoli, 2013 ${ }^{21}$ & Farming & RR & $1.32(1.11-1.57)$ & 0.087 & 37.3 & 0.219 & 10 & 5.18 & 0.022 \\
\hline Pezzoli, 2013 ${ }^{21}$ & Organic solvents & $\mathrm{RR}$ & $1.06(0.86-1.30)$ & 0.105 & 43.6 & 0.024 & 3 & 0.96 & 0.032 \\
\hline $\begin{array}{l}\text { van der Mark, } \\
2012^{22}\end{array}$ & Pesticides & RR & $1.11(0.89-1.38)$ & 0.112 & 63.7 & 0.057 & 17 & 2.27 & $<1.0 \times 10^{-8}$ \\
\hline Pezzoli, 2013 ${ }^{21}$ & Rural living & RR & $1.00(0.99-1.01)$ & 0.005 & 78.6 & 0.001 & 9 & 1.55 & $<1.0 \times 10^{-8}$ \\
\hline Noyce, $2012^{23}$ & Well water drinking & $\mathrm{RR}$ & $1.23(0.99-1.52)$ & 0.107 & 70.6 & $0.005^{*}$ & 10 & 2.26 & $<1.0 \times 10^{-8}$ \\
\hline \multicolumn{10}{|l|}{ Dietary factors } \\
\hline Etminan, $2005^{89}$ & Vitamin $\mathrm{C}$ intake & OR & $0.78(0.61-1.01)$ & 0.129 & 38.1 & 0.165 & 0 & 0.72 & NP \\
\hline Etminan, $2005^{89}$ & Vitamin E intake & OR & $0.69(0.49-0.98)$ & 0.177 & 0 & 0.264 & 1 & 0.92 & 0.926 \\
\hline Jiang, $2014^{90}$ & Dairy products intake & RR & $1.33(1.07-1.65)$ & 0.110 & 8.2 & 0.615 & 4 & 0.95 & $7.7 \times 10^{-4}$ \\
\hline Takeda, $2014^{91}$ & Lutein intake & OR & $0.78(0.56-1.09)$ & 0.170 & 77.8 & 0.096 & 2 & 0.47 & 0.018 \\
\hline Takeda, $2014^{91}$ & Lycopene intake & OR & $0.87(0.63-1.20)$ & 0.164 & 62.3 & 0.983 & 1 & 0.22 & 0.085 \\
\hline Takeda, $2014^{91}$ & Vitamin A intake & OR & $1.16(0.85-1.58)$ & 0.158 & 0 & 0.444 & 0 & 0.22 & NP \\
\hline Takeda, $2014^{91}$ & $\alpha$-carotene intake & OR & $0.91(0.64-1.29)$ & 0.179 & 22.9 & 0.847 & 0 & 0.18 & NP \\
\hline Takeda, $2014^{91}$ & $\beta$-carotene intake & OR & $0.90(0.63-1.29)$ & 0.183 & 37.5 & 0.862 & 1 & 0.37 & 0.286 \\
\hline Takeda, $2014^{91}$ & $\beta$-cryptoxanthin intake & OR & $0.74(0.53-1.03)$ & 0.169 & 42.1 & 0.271 & 0 & 0.49 & $\mathrm{NP}$ \\
\hline Wang, $2014^{92}$ & Carbohydrate intake & RR & $1.29(0.98-1.70)$ & 0.141 & 0 & 0.613 & 1 & 0.91 & 0.917 \\
\hline
\end{tabular}




\begin{tabular}{|c|c|c|c|c|c|c|c|c|c|}
\hline Wang, $2014^{92}$ & Cholesterol intake & RR & $0.87(0.69-1.10)$ & 0.119 & 62.4 & 0.273 & 2 & 0.48 & 0.022 \\
\hline Wang, $2014^{92}$ & Energy intake & RR & $0.97(0.93-1.02)$ & 0.024 & 83.8 & 0.084 & 2 & 0.41 & 0.010 \\
\hline Wang, $2014^{92}$ & Protein intake & RR & $1.60(1.10-2.20)$ & 0.177 & 30.4 & 0.676 & 1 & 2.32 & NP \\
\hline Wang, $2014^{92}$ & Total fat intake & RR & $0.69(0.52-0.91)$ & 0.143 & 34.4 & $0.070^{*}$ & 2 & 2.52 & NP \\
\hline \multicolumn{10}{|c|}{ Medical history and comorbid diseases } \\
\hline $\begin{array}{l}\text { Cereda, } 2011^{24} \\
\text { and } \mathrm{Lu}, 2014^{25}\end{array}$ & Diabetes mellitus & OR & $1.41(1.20-1.66)$ & 0.083 & 78.1 & $0.035^{*}$ & 9 & 6.74 & 0.270 \\
\hline Jafari, $2013^{57}$ & Head injury & OR & $1.94(1.69-2.23)$ & 0.071 & 61 & 0.569 & 10 & 8.58 & 0.533 \\
\hline Liu, $2011^{93}$ & Melanoma & OR & $1.44(1.03-2.01)$ & 0.171 & 24.1 & 0.718 & 1 & 2.77 & NP \\
\hline Noyce, $2012^{23}$ & Anxiety or Depression & RR & $1.79(1.72-1.86)$ & 0.020 & 67.7 & 0.755 & 10 & 7.3 & 0.132 \\
\hline Noyce, $2012^{23}$ & Cancer & RR & $1.04(0.96-1.12)$ & 0.039 & 50.4 & 0.132 & 1 & 0.43 & 0.364 \\
\hline Noyce, $2012^{23}$ & Constipation & RR & $2.18(1.32-3.61)$ & 0.257 & 0 & $\mathrm{NE}$ & 2 & 0.9 & 0.116 \\
\hline Noyce, $2012^{23}$ & Gastric ulcer & RR & $0.47(0.25-0.84)$ & 0.309 & 81 & $0.072 *$ & 2 & 1.04 & 0.243 \\
\hline Noyce, $2012^{23}$ & Hypertension & RR & $0.96(0.80-1.15)$ & 0.093 & 76.4 & 0.392 & 5 & 0.64 & $2.0 \times 10^{-8}$ \\
\hline Noyce, $2012^{23}$ & Oophorectomy & RR & $0.75(0.56-0.99)$ & 0.145 & 58.8 & 0.931 & 2 & 0.55 & 0.039 \\
\hline Shen, $2013^{26}$ & Gout & RR & $0.70(0.59-0.83)$ & 0.087 & 0 & $\mathrm{NE}$ & 2 & 1.56 & 0.452 \\
\hline \multicolumn{10}{|l|}{ Drugs } \\
\hline Gagne, $2010^{94}$ & Aspirin & RR & $1.13(0.96-1.33)$ & 0.083 & 50.3 & 0.335 & 1 & 0.53 & 0.497 \\
\hline Gagne, $2010^{94}$ & Non-aspirin NSAIDs & RR & $0.93(0.80-1.08)$ & 0.077 & 0.1 & 0.034 & 1 & 0.45 & 0.393 \\
\hline Gao, $2011^{76}$ & Acetaminophen & RR & $1.16(1.00-1.35)$ & 0.077 & 0 & $0.058^{*}$ & 0 & 0.48 & NP \\
\hline Gao, $2011^{76}$ & Ibuprofen & RR & $0.77(0.61-0.98)$ & 0.121 & 0 & 0.588 & 3 & 1.12 & 0.044 \\
\hline Noyce, $2012^{23}$ & Beta-blockers & RR & $1.28(1.16-1.41)$ & 0.050 & 0 & 0.403 & 2 & 1.48 & 0.546 \\
\hline Lang, $2015^{95}$ & Calcium channel blockers & RR & $0.70(0.61-0.81)$ & 0.074 & 25.7 & 0.128 & 2 & 2.03 & NP \\
\hline Noyce, $2012^{23}$ & General anesthesia & RR & $0.74(0.61-0.91)$ & 0.102 & 74.2 & 0.195 & 2 & 0.92 & 0.223 \\
\hline Noyce, $2012^{23}$ & Oral contraceptives & RR & $1.02(0.77-1.36)$ & 0.145 & 71.1 & 0.390 & 1 & 0.15 & 0.025 \\
\hline Undela, $2013^{96}$ & Statins & RR & $0.94(0.82-1.09)$ & 0.073 & 62.9 & 0.015 & 2 & 0.7 & 0.105 \\
\hline Wang, $2015^{97}$ & Hormone Replacement Therapy & RR & $1.21(1.00-1.46)$ & 0.097 & 50.4 & $0.013^{*}$ & 4 & 1.45 & 0.025 \\
\hline \multicolumn{10}{|l|}{ Biomarkers } \\
\hline Chen, $2014^{98}$ & $\begin{array}{l}\text { BMI } \\
(\mathrm{BMI} \geq 30 \text { vs. } \mathrm{BMI}<25)\end{array}$ & OR & $2.34(1.83-2.97)$ & 0.124 & 90.6 & 0.189 & 2 & 4.94 & NP \\
\hline Chen, $2014^{98}$ & $\begin{array}{l}\mathrm{BMI} \\
(\mathrm{BMI} \geq 30 \text { vs. } 25 \bullet \mathrm{BMI}<30)\end{array}$ & OR & $1.20(0.96-1.50)$ & 0.114 & 71.5 & 0.319 & 3 & 0.68 & 0.003 \\
\hline Chen, 2014 ${ }^{98}$ & $\begin{array}{l}\text { BMI } \\
(25 \bullet \mathrm{BMI}<30 \text { vs. } \mathrm{BMI}<25)\end{array}$ & OR & $1.16(0.99-1.37)$ & 0.083 & 85.2 & 0.541 & 2 & 0.67 & 0.088 \\
\hline
\end{tabular}




\begin{tabular}{|c|c|c|c|c|c|c|c|c|c|}
\hline Gao, $2014^{52}$ & $\alpha$-synuclein in CSF & OR & $1.17(0.75-1.84)$ & 0.230 & 91.7 & 0.120 & 7 & 0.60 & $<1.0 \times 10^{-8}$ \\
\hline Gudala, $2013^{99}$ & Serum cholesterol & RR & $1.06(0.88-1.26)$ & 0.092 & 70.3 & 0.234 & 2 & 0.48 & 0.023 \\
\hline $\mathrm{Lv}, 2014^{51}$ & Serum vitamin D & OR & $0.73(0.55-0.96)$ & 0.142 & 97.7 & 0.063 & 7 & 0.71 & $<1.0 \times 10^{-8}$ \\
\hline Mariani, $2013^{56}$ & Copper in plasma & OR & $\begin{array}{l}85.10(44.70- \\
162.02)\end{array}$ & 0.329 & 98.7 & 0.272 & 3 & 3.96 & NP \\
\hline Mariani, $2013^{56}$ & Copper in CSF & OR & $0.91(0.40-2.08)$ & 0.421 & 83.8 & 0.680 & 2 & 0.25 & $3.8 \times 10^{-4}$ \\
\hline Mariani, $2013^{56}$ & Serum copper & OR & $0.66(0.32-1.35)$ & 0.366 & 92.6 & 0.913 & 4 & 0.63 & $1.0 \times 10^{-5}$ \\
\hline Mariani, $2013^{56}$ & Iron in CSF & OR & $0.64(0.28-1.45)$ & 0.421 & 79.8 & 0.487 & 2 & 0.34 & $3.2 \times 10^{-3}$ \\
\hline Mariani, $2013^{56}$ & Serum iron & OR & $0.16(0.11-0.24)$ & 0.204 & 93.6 & 0.615 & 7 & 5.14 & 0.240 \\
\hline Sako, 2014 & Nigral volume loss & OR & $0.22(0.11-0.42)$ & 0.333 & 47.4 & 0.917 & 3 & 1.74 & 0.280 \\
\hline Shen, $2013^{26}$ & Serum urate & $\mathrm{RR}$ & $0.60(0.30-1.10)$ & 0.331 & 42.1 & 0.390 & 2 & 1.37 & 0.556 \\
\hline Shen, $2013^{55}$ & Serum uric acid & OR & $0.23(0.19-0.29)$ & 0.111 & 75.9 & 0.286 & 4 & 3.74 & 0.830 \\
\hline $\mathrm{Yu}, 2014^{54}$ & RNFLT & OR & $0.58(0.35-0.95)$ & 0.258 & 81 & 0.969 & 8 & 1.26 & $<1.0 \times 10^{-8}$ \\
\hline Zhao, $2013^{53}$ & BMD in femoral neck & OR & $0.47(0.31-0.71)$ & 0.213 & 95.6 & 0.267 & 5 & 1.81 & 0.007 \\
\hline Zhao, $2013^{53}$ & BMD in hip & OR & $0.95(0.62-1.44)$ & 0.213 & 61.8 & 0.192 & 4 & 0.30 & $<1.0 \times 10^{-8}$ \\
\hline Zhao, $2013^{53}$ & BMD in lumbar spine & OR & $0.90(0.59-1.37)$ & 0.217 & 89 & 0.747 & 6 & 0.48 & $<1.0 \times 10^{-8}$ \\
\hline Zhao, $2013^{53}$ & BMD in trochanter & OR & $0.86(0.57-1.31)$ & 0.213 & 45.6 & 0.733 & 1 & 0.22 & 0.090 \\
\hline
\end{tabular}

BMD: bone mineral density, BMI: body mass index, CI: confidence interval, CSF: cerebrospinal fluid, HR: hazard ratio, NSAIDs: non-steroidal anti-inflammatory drugs, NE: not estimable, OR: odds ratio, PI: prediction interval RR: risk ratio, RNFLT: retinal nerve fiber layer thickness

*In the annotated papers, the Egger test was statistically significant $(\mathrm{p}<0.10)$ but the largest study has larger effect size compared to the summary effect size under random effects, denoting the absence of small-study effects 
Table 3. Assessment across the 66 associations of environmental risk factors with Parkinson's disease

Association does NOT imply causation. See Discussion for alternative explanations for convincing and suggestive associations.

\begin{tabular}{|c|c|c|c|c|c|c|}
\hline Risk factors & $\begin{array}{l}\text { Sample size } \\
\text { (number of } \\
\text { cases) }\end{array}$ & $\begin{array}{l}\text { Estimate of } \\
\text { heterogeneity }\end{array}$ & $\begin{array}{l}\text { 95\% prediction } \\
\text { interval }\end{array}$ & $\begin{array}{l}\text { Small-study effect or } \\
\text { excess significance } \\
\text { bias }\end{array}$ & $\begin{array}{l}\text { Random effects } \\
\text { summary effect size } \\
(95 \% \text { CI })\end{array}$ & $\begin{array}{l}\text { Significance threshold } \\
\text { reached (under the random- } \\
\text { effects model) }\end{array}$ \\
\hline \multicolumn{7}{|c|}{ Associations supported by highly suggestive evidence } \\
\hline Anxiety or depression ${ }^{23}$ & $>1000$ & Large & Excluding the null value & Neither & $1.86(1.64-2.10)$ & $<10^{-6}$ \\
\hline Beta-blockers $^{23}$ & $>1000$ & Not large & Including the null value & Neither & $1.28(1.19-1.39)$ & $<10^{-6}$ \\
\hline Head injury $^{57}$ & $>1000$ & Large & Including the null value & Neither & $1.55(1.33-1.81)$ & $<10^{-6}$ \\
\hline Physical activity $^{58}$ & $>1000$ & Not large & Excluding the null value & Excess significance bias & $0.66(0.57-0.78)$ & $<10^{-6}$ \\
\hline Serum uric acid ${ }^{55}$ & $>1000$ & Very large & Including the null value & Neither & $0.39(0.27-0.57)$ & $<10^{-6}$ \\
\hline Smoking $^{23}$ & $>1000$ & Not large & Excluding the null value & Both & $0.64(0.60-0.69)$ & $<10^{-6}$ \\
\hline \multicolumn{7}{|c|}{ Associations supported by suggestive evidence } \\
\hline Alcohol intake ${ }^{85}$ & $>1000$ & Large & Including the null value & Both & $0.75(0.66-0.85)$ & $<0.001$ but $>10^{-6}$ \\
\hline $\begin{array}{l}\text { Calcium } \\
\text { blockers }^{95}\end{array}$ & $>1000$ & Not large & Including the null value & Neither & $0.78(0.67-0.90)$ & $<0.001$ but $>10^{-6}$ \\
\hline Coffee drinking $^{23}$ & $>1000$ & Not large & Excluding the null value & Both & $0.67(0.58-0.76)$ & $<10^{-6}$ \\
\hline Dairy products intake ${ }^{90}$ & $>1000$ & Not large & Excluding the null value & Excess significance bias & $1.40(1.20-1.63)$ & $<0.001$ but $>10^{-6}$ \\
\hline Farming $^{21}$ & $>1000$ & Not large & Including the null value & Excess significance bias & $1.30(1.16-1.46)$ & $<0.001$ but $>10^{-6}$ \\
\hline Ibuprofen $^{76}$ & $>1000$ & Not large & Excluding the null value & Excess significance bias & $0.73(0.62-0.85)$ & $<0.001$ but $>10^{-6}$ \\
\hline Pesticides $^{22}$ & $>1000$ & Large & Including the null value & Both & $1.62(1.40-1.88)$ & $<10^{-6}$ \\
\hline
\end{tabular}




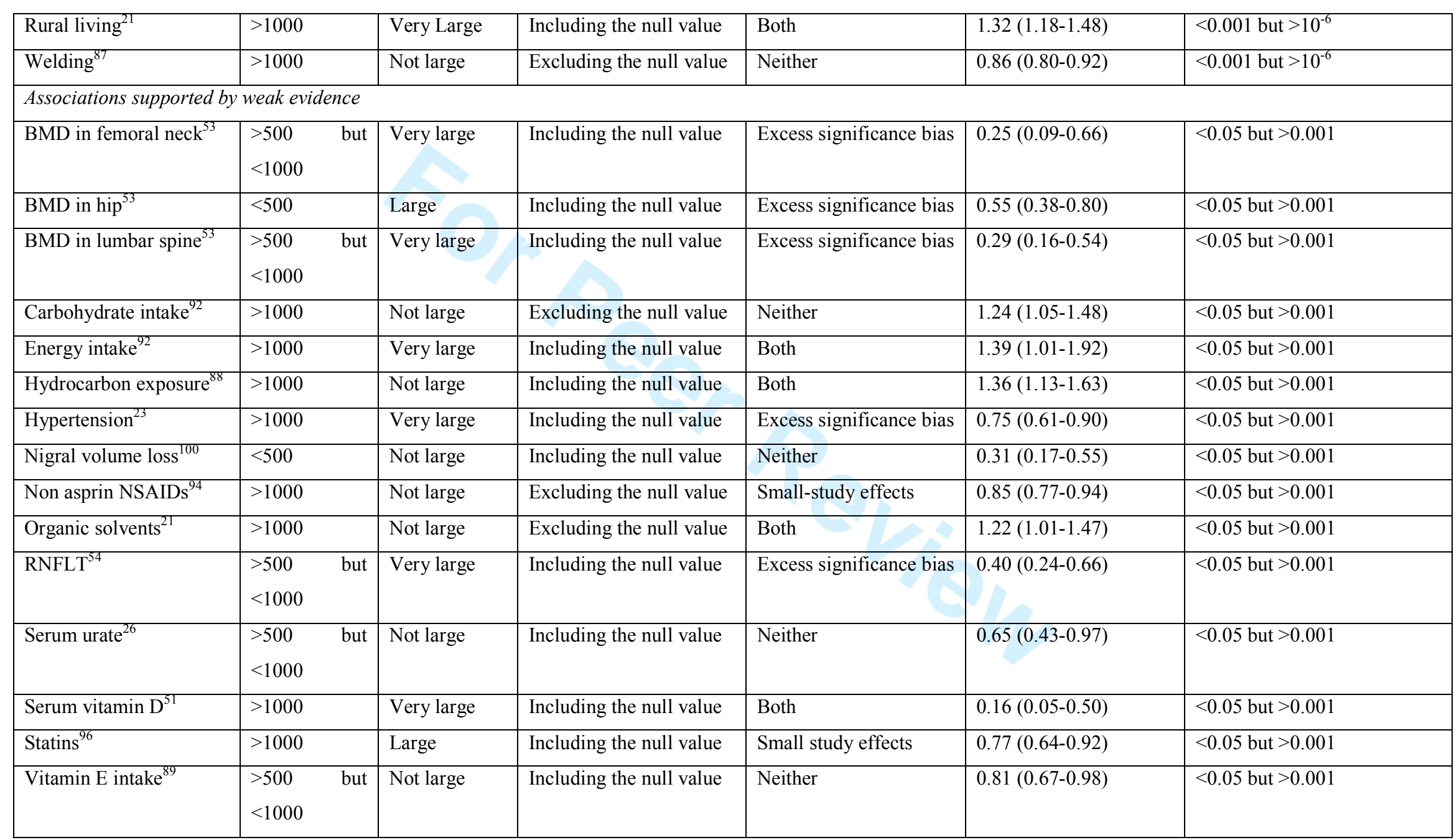




\begin{tabular}{|c|c|c|c|c|c|c|}
\hline Well water drinking ${ }^{23}$ & $>1000$ & Large & Including the null value & Excess significance bias & $1.21(1.05-1.40)$ & $<0.05$ but $>0.001$ \\
\hline$\alpha$-synuclein in $\operatorname{CSF}^{52}$ & $\begin{array}{ll}>500 \quad \text { but } \\
<1000\end{array}$ & Very large & Including the null value & Excess significance bias & $0.29(0.13-0.62)$ & $<0.05$ but $>0.001$ \\
\hline \multicolumn{7}{|c|}{ Associations not adequately assessed owing to small number of studies } \\
\hline Constipation $^{23}$ & $<500$ & Not large & NA & NA & $2.34(1.55-3.53)$ & $<0.001$ \\
\hline Gout $^{26}$ & $>1000$ & Not large & NA & NA & $0.70(0.60-0.82)$ & $<0.001$ \\
\hline \multicolumn{7}{|l|}{ Not significant associations } \\
\hline Acetaminophen intake $^{76}$ & $>1000$ & Not large & Including the null value & Neither & $1.09(0.96-1.24)$ & $>0.05$ \\
\hline Aspirin intake $^{94}$ & $>1000$ & Large & Including the null value & Neither & $1.08(0.93-1.27)$ & $>0.05$ \\
\hline BMD in trochanter ${ }^{53}$ & $<500$ & Not large & Including the null value & Neither & $0.73(0.48-1.11)$ & $>0.05$ \\
\hline $\begin{array}{l}\mathrm{BMI} \\
(\mathrm{BMI} \geq 30 \text { vs. } \mathrm{BMI}< \\
25)^{98}\end{array}$ & $>1000$ & Very large & Including the null value & Neither & $0.96(0.61-1.50)$ & $>0.05$ \\
\hline $\begin{array}{l}\text { BMI } \\
(\mathrm{BMI} \geq 30 \text { vs. } 25 \bullet \mathrm{BMI}< \\
30)^{98}\end{array}$ & $>1000$ & Large & Including the null value & Excess significance bias & $0.83(0.65-1.07)$ & $>0.05$ \\
\hline $\begin{array}{l}\text { BMI } \\
(25 \bullet \mathrm{BMI}<30 \text { vs. } \\
\mathrm{BMI}<25)^{98}\end{array}$ & $>1000$ & Very large & Including the null value & Excess significance bias & $1.20(0.94-1.53)$ & $>0.05$ \\
\hline Cancer $^{23}$ & $>1000$ & Large & Including the null value & Neither & $0.89(0.72-1.10)$ & $>0.05$ \\
\hline Cholesterol intake $^{92}$ & $>1000$ & Large & Including the null value & Excess significance bias & $0.97(0.75-1.26)$ & $>0.05$ \\
\hline Copper in plasma $^{56}$ & $<500$ & Very large & Including the null value & Neither & $1.41(0.03-59.27)$ & $>0.05$ \\
\hline Copper in $\mathrm{CSF}^{56}$ & $<500$ & Very large & Including the null value & Excess significance bias & $2.06(0.57-7.44)$ & $>0.05$ \\
\hline Diabetes mellitus $^{24,25}$ & $>1000$ & Very large & Including the null value & Neither & $0.91(0.74-1.11)$ & $>0.05$ \\
\hline Gastric ulcer $^{23}$ & $<500$ & Very large & Including the null value & Neither & $1.37(0.36-5.31)$ & $>0.05$ \\
\hline General anesthesia $^{23}$ & $>1000$ & Large & Including the null value & Neither & $1.10(0.77-1.58)$ & $>0.05$ \\
\hline
\end{tabular}




\begin{tabular}{|c|c|c|c|c|c|c|}
\hline $\begin{array}{ll}\text { Hormone } & \text { replacement } \\
\text { therapy }^{97} & \end{array}$ & $>1000$ & Large & Including the null value & Excess significance bias & $1(0.84-1.20)$ & $>0.05$ \\
\hline Iron in $\mathrm{CSF}^{56}$ & $<500$ & Very large & Including the null value & Excess significance bias & $0.93(0.35-2.45)$ & $>0.05$ \\
\hline Lutein intake $^{91}$ & $\begin{array}{l}>500 \quad \text { but } \\
<1000\end{array}$ & Very large & Including the null value & Both & $1.49(0.83-2.68)$ & $>0.05$ \\
\hline Lycopene intake $^{91}$ & $\begin{array}{lr}>500 & \text { but } \\
<1000 & \end{array}$ & Large & Including the null value & Neither & $1.03(0.64-1.65)$ & $>0.05$ \\
\hline Melanoma $^{93}$ & $>1000$ & Not large & Including the null value & Neither & $1.13(0.73-1.76)$ & $>0.05$ \\
\hline Oophorectomy $y^{23}$ & $\begin{array}{ll}>500 & \text { but } \\
<1000 & \end{array}$ & Large & Including the null value & Excess significance bias & $0.77(0.52-1.13)$ & $>0.05$ \\
\hline Oral contraceptives ${ }^{23}$ & $\begin{array}{l}>500 \quad \text { but } \\
<1000\end{array}$ & Large & Including the null value & Excess significance bias & $0.73(0.43-1.25)$ & $>0.05$ \\
\hline Serum iron ${ }^{56}$ & $\begin{array}{l}>500 \quad \text { but } \\
<1000\end{array}$ & Very large & Including the null value & Neither & $0.45(0.17-1.17)$ & $>0.05$ \\
\hline Tea intake $^{86}$ & $>1000$ & Large & Including the null value & Excess significance bias & $0.86(0.68-1.08)$ & $>0.05$ \\
\hline Total fat intake ${ }^{92}$ & $>1000$ & Not large & Including the null value & Neither & $0.88(0.74-1.06)$ & $>0.05$ \\
\hline Vitamin A intake $^{91}$ & $\begin{array}{l}>500 \quad \text { but } \\
<1000\end{array}$ & Not large & Including the null value & Neither & $1.09(0.84-1.42)$ & $>0.05$ \\
\hline Vitamin C intake $^{89}$ & $>1000$ & Not large & Including the null value & Neither & $1.06(0.86-1.30)$ & $>0.05$ \\
\hline
\end{tabular}




\section{Page 39 of 40}

\section{Movement Disorders}

\begin{tabular}{|l|l|l|l|l|l|l|l|}
\hline$\alpha$-carotene intake & $\begin{array}{l}>500 \\
<1000\end{array}$ & but & Not large & Including the null value & Neither & $0.84(0.59-1.18)$ & $>0.05$ \\
\hline$\beta$-carotene intake & $>1000$ & Not large & Including the null value & Neither & $0.92(0.70-1.20)$ & $>0.05$ \\
\hline$\beta$-cryptoxanthin intake & $\begin{array}{l}>500 \\
<1000\end{array}$ & but & Not large & Including the null value & Neither & $0.96(0.66-1.40)$ & $>0.05$ \\
\hline
\end{tabular}


Table 4. Quality assessments of primary studies. 13 papers assessed the quality of the primary observational studies using the Newcastle Ottawa Scale (NOS). Two additional papers used different methods to assess the included studies (criteria set by authors in the case of Cereda 2011 and QUADAS-2 in the case of Gao 2014). The other 18 papers did not perform any quality assessment.

\begin{tabular}{|c|c|c|c|c|}
\hline Reference & Risk factor & $\begin{array}{l}\text { High quality } \\
(\text { NOS score }=9)\end{array}$ & $\begin{array}{l}\text { Moderate quality } \\
\text { (NOS score }=7 \text { or } 8 \text { ) }\end{array}$ & $\begin{array}{l}\text { Low quality } \\
\text { (NOS score }<7 \text { ) }\end{array}$ \\
\hline \multirow{2}{*}{ Gagne, $2010^{94}$} & Aspirin & 0 & 6 & 0 \\
\hline & Non-aspirin NSAIDs & 0 & 7 & 0 \\
\hline Gudala, $2013^{99}$ & Serum cholesterol & 3 & 1 & 4 \\
\hline Jafari, $2013^{57}$ & Head injury & 6 & 7 & 9 \\
\hline Lang, 2015* & Calcium channel blockers & 0 & 5 & 0 \\
\hline $\mathrm{Lu}, 2014^{25}$ & Diabetes mellitus & 0 & 6 & 8 \\
\hline $\mathrm{Lv}, 2014^{51}$ & Serum vitamin D & 2 & 5 & 0 \\
\hline \multirow{3}{*}{ Pezzoli, $2013^{21}$} & Farming & 0 & 16 & 21 \\
\hline & Organic solvents & 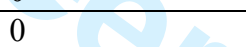 & 7 & 11 \\
\hline & Rural living & 0 & 4 & 27 \\
\hline \multirow{2}{*}{ Shen, $2013^{26} *$} & Serum urate & 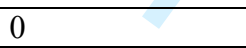 & 6 & 0 \\
\hline & Gout & 0 & 2 & 0 \\
\hline \multirow{6}{*}{ Takeda, $2014^{91}$} & Lutein intake & 0 & 3 & 1 \\
\hline & Lycopene intake & 0 & 2 & 1 \\
\hline & Vitamin A intake & 0 & 2 & 1 \\
\hline & $\alpha$-carotene intake & 0 & 1 & 2 \\
\hline & $\beta$-carotene intake & 0 & +2 & 3 \\
\hline & $\beta$-cryptoxanthin intake & 0 & $1+2-x$ & 2 \\
\hline Undela, $2013^{96}$ & Statins & 1 & 5 & 2 \\
\hline Wang, $2015^{97}$ & Hormone replacement therapy & 0 & +2 & 8 \\
\hline $\mathrm{Yu}, 2014^{54} *$ & RNFLT & 0 & 11 & 2 \\
\hline Zhang, $2014^{85}$ & Alcohol & 0 & 12 & 21 \\
\hline
\end{tabular}

*These papers used as a threshold for moderate quality a NOS score $=6$ 